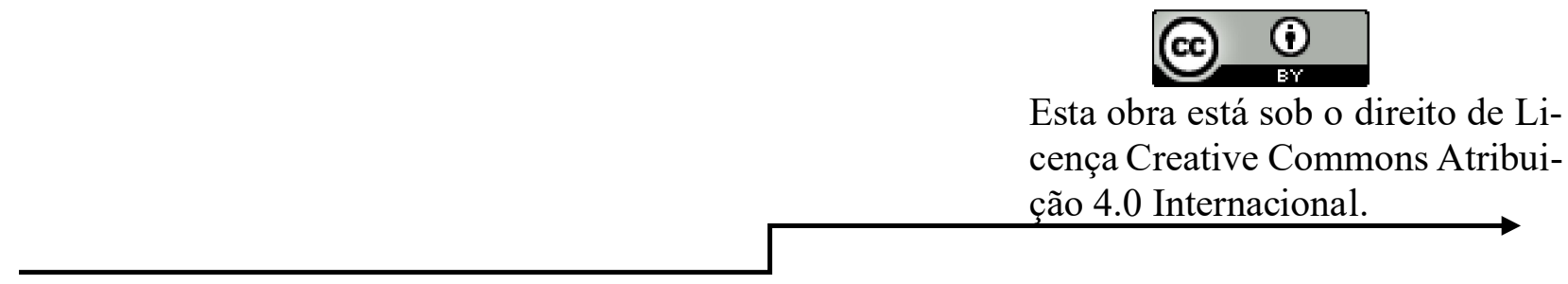

\title{
A LEGISLAÇÃO E SUA UTLIZAÇÃO NO COMBATE A EVASÃO ESCOLAR
}

Justina Pacheco de Vasconcelos 1

Andrea Marques Vanderlei Fregadolli ${ }^{2}$

\section{RESUMO}

Objetivo: analisar a legislação e sua utilização no combate à evasão escolar no ensino básico. Método: trata-se de uma pesquisa documental sistemática. O descritor estruturado no DeCS (13719) e MeSH (D013332), evasão escolar, foi utiliza do no Portal Jusbrasil para obtenção dos documentos. O período de coleta dos dados compreendeu os meses de julho e agosto de 2019. Adotaram-se como critérios de inclusão: artigo de opinião de especialista publicados nos últimos 5 anos. Enquanto que, os critérios de exclusão foram: artigos de opinião que não contemplam a temática legislação e sua utilização no combate à evasão escolar. Resultados: Dos 29 documentos disponíveis na plataforma Jusbrasil, após aplicar os filtros, todos obedeceram aos critérios de inclusão, sendo submetidos às seis etapas da pesquisa documental sistemática. As categorias temáticas desenvolvidas a partir da análise dos trabalhos foram: 1 - Garantias do direito ao acesso à educação de qualidade a todos; 2 -Transporte escolar, demanda básica para o acesso à escola; 3 - A evasão escolar diante da realidade social do educando; 4 - A importância do comprimento da legislação, quanto ao casamento e o trabalho infantil, para o futuro do educando; 5 - O processo de inclusão nas escolas, levando em consideração as garantias da Legislação; 6 - A falta de Inclusão dos educandos LGBT no ambiente escolar . Conclusão: a falta de políticas públicas eficazes, para questões relacionadas a condição social do educando, a acessibilidade e a inclusão, provocam o desrespeito às leis, tendo como consequência o alto índice de evasão escolar.

Palavras-chave: Evasão escolar.

\footnotetext{
${ }^{1}$ Mestranda em Ciências da Educação (Absoulute Christian University).

2 Doutora em Ciências (UFAL). Mestre em Modelagem Computacional do Conhecimento (UFAL). Professora da graduação de Medicina e do Mestrado Ensino na Saúde da Faculdade de Medicina (UFAL).
} 


\section{INTRODUÇÃO}

A legislação brasileira é bastante ampla no que diz respeito as garantias do direito de todos os cidadãos a educação de qualidade, é dever do Estado a garantia de ensino fundamental, obrigatório e gratuito, assegurada, inclusive, sua oferta gratuita para todos os que a ele não tiveram acesso na idade própria, assegurando atendimento educacional especializado aos portadores de deficiência, preferencialmente na rede regular de ensino, os educando que só podem estudar a noite também tem seu direito garantido, como também atendimento ao educando, no ensino fundamental, através de programas suplementares de material didático-escolar, transporte, alimentação e assistência à saúde, a educação infantil, em creche e pré-escola, às crianças até 5 anos de idade, também tem garantia (artigo Art. 208 da Constituição Federal de 1988).

Mesmo diante dos problemas enfrentados no sistema educacional brasileiro, a Constituição Federal é de fundamental importância na garantia da busca de políticas públicas para um ensino de qualidade. Desde sua promulgação, vem sendo feitas na constituição, adequações, modificações e criação de Leis, para atender as necessidades e demandas da sociedade no contexto educacional.

No ano de 1990, foi criada a Lei 8.069 que trata o estatuto da Criança e do Adolescente, que entre outros objetivos, pretende fortalecer o direito ao acesso e permanência na escola. Esta Lei dispõe sobre a proteção integral à criança e ao adolescente, considerando-se criança a pessoa até doze anos de idade incompletos, e adolescentes, jovens entre doze e dezoitos anos de idade, e excepcionalmente, o estatuto e aplicado às pessoas entre dezoito e vinte e um anos de idade (ECA, 1990).

Em 1996 foi criado a Lei 9.394, que estabelece as Diretrizes e Bases da Educação Nacional, definindo entre outros no seu Art. $2^{\circ}$ que a educação é dever da família e do Estado, inspirada nos princípios de liberdade e nos ideais de solidariedade humana, tem por finalidade o pleno desenvolvimento do educando, seu preparo para o exercício da cidadania e sua qualificação para o trabalho (LDB 1996).

Um importante instrumento foi criado em 2015, no fortalecimento da garantia do direito a educação entre outros, da pessoa com deficiência, Lei 13.146, onde é instituída a Lei Brasileira de Inclusão da Pessoa com Deficiência (Estatuto da Pessoa com Deficiência), destinada a assegurar e a promover, em condições de igualdade, o exercício dos direitos e das liberdades fundamentais por pessoa com deficiência, visando à sua inclusão social e cidadania. 
(EPD, 2015). Sabe-se que sem educação, não há cidadania.

Este artigo trata da Leis em prol do combate a infrequência dos educandos, e tem o objetivo analisar a legislação e sua

\section{MÉTODO}

Trata-se de uma pesquisa documental sistemática, a qual seguiu as seguintes etapas (Quadro 1): $1^{\mathrm{a}}$ - definição do tema, seleção da pergunta norteadora e escolha da estratégia de busca; descritores e bases de dados mais eficazes no levantamento das publicações; $2^{\mathrm{a}}$ - período da coleta de dados, escolha dos critérios de inclusão e exclusão; $3^{\mathrm{a}}$ - identificação dos estudos pré-selecionados e selecionados por meio da leitura dos agentes indexadores das publicações, como resumos, palavras-chave e títulos, bem como a organização dos estudos utilização no combate à evasão escolar no ensino básico. Esta pesquisa partiu da seguinte pergunta norteadora: As leis que regem a educação básica, são eficazes no combate à evasão escolar?

pré-selecionados e a identificação dos estudos selecionados; $4^{\mathrm{a}}$ - categorização dos estudos selecionados, com a elaboração e o uso da matriz de síntese, além da análise das informações; a formação de uma biblioteca individual e a avaliação crítica dos estudos selecionados; $5^{\mathrm{a}}$ - análise, interpretação e discussão dos resultados, e $6^{\mathrm{a}}$ - a apresentação da revisão em formato de artigo, o qual contempla as propostas para estudos futuros.

Figura 1 - Detalhamento da pesquisa documental sistemática.

\begin{tabular}{|c|c|c|}
\hline ETAPA & $\begin{array}{c}\text { TÓPICOS DE CADA } \\
\text { ETAPA } \\
\end{array}$ & DETALHAMENTO DE CADA TÓPICO \\
\hline \multirow[t]{6}{*}{$1^{\mathrm{a}}$} & Tema & A legislação em prol do combate a evasão escolar \\
\hline & Pergunta norteadora & $\begin{array}{l}\text { As leis que regem a educação básica, são eficazes no } \\
\text { combate a evasão escolar? }\end{array}$ \\
\hline & Objetivo geral & $\begin{array}{l}\text { Analisar a legislação e sua utilização no combate à } \\
\text { evasão escolar no ensino básico. }\end{array}$ \\
\hline & Estratégia de busca & $\begin{array}{l}\text { 1. Cruzamento de descritores, quando necessário, por } \\
\text { meio do operador boleando AND; } \\
\text { 2. Uso de descritores estruturados (codificação no } \\
\text { DECS ou MESH. } \\
\text { 3. Uso de metadados (filtros) nas bibliotecas virtuais; } \\
\text { 4. Uso de aspas nos politermos, para que a varredura } \\
\text { de artigos científicos contemplasse o termo exato } \\
\text { 5. Uso de descritores em português }\end{array}$ \\
\hline & $\begin{array}{l}\text { Descritores estruturados no } \\
\text { DECS e MASH e livres. }\end{array}$ & 1. evasão escolar (DECS 13719), (MESH D013332) \\
\hline & Bibliotecas Virtuais & 1. JUSBRASIL \\
\hline $2^{\mathrm{a}}$ & Período de coleta dos dados & Julho e agosto de $2019 .$. \\
\hline
\end{tabular}




\begin{tabular}{|c|c|c|}
\hline & Critérios de inclusão & $\begin{array}{l}\text { 2. Texto (artigo de opinião de especialista, ou diários } \\
\text { oficias, ou jurisprudência). } \\
\text { 3. Publicação (2014-2019). }\end{array}$ \\
\hline & Critérios de exclusão & $\begin{array}{l}\text { Artigos, diários oficiais, ou jurisprudência que não } \\
\text { contemplam a temática legislação e sua utilização no } \\
\text { combate a evasão escolar. }\end{array}$ \\
\hline $3^{\mathrm{a}}$ & $\begin{array}{l}\text { Número de trabalhos selecio- } \\
\text { nados para revisão sistemá- } \\
\text { tica integrativa a partir da } \\
\text { leitura dos agentes indexado- } \\
\text { res das publicações (resumo, } \\
\text { palavras-chave e título) e re- } \\
\text { sultados, os quais devem } \\
\text { conter os descritores utiliza- } \\
\text { dos nesse estudo. }\end{array}$ & 29 trabalhos. \\
\hline $4^{\mathrm{a}}$ & $\begin{array}{l}\text { Categorias obtidas com a } \\
\text { análise dos trabalhos científi- } \\
\text { cos investigados. }\end{array}$ & $\begin{array}{l}1 \text { - Garantias do direito ao acesso a educação de quali- } \\
\text { dade a todos; } \\
2 \text {-Transporte escolar, demanda básica para o acesso a } \\
\text { escola; } \\
3 \text { - A evasão escolar diante da realidade social do edu- } \\
\text { cando; } \\
4 \text { - A importância do comprimento da legislação, } \\
\text { quanto ao casamento e o trabalho infantil, para o } \\
\text { futuro do educando; } \\
5 \text { - O processo de inclusão nas escolas, levando em } \\
\text { consideração as garantias da Legislação; } \\
6 \text { - A falta de Inclusão dos educandos LGBT no am- } \\
\text { biente escolar }\end{array}$ \\
\hline $5^{\mathrm{a}}$ & $\begin{array}{l}\text { Analise, interpretação e dis- } \\
\text { cursão dos resultados }\end{array}$ & Ver em "Resultados e Discursão" \\
\hline $6^{\mathrm{a}}$ & $\begin{array}{l}\text { Apresentação da revisão em } \\
\text { formato de artigo, o qual } \\
\text { contemple propostas para es- } \\
\text { tudos futuros. }\end{array}$ & Esse Artigo completo. \\
\hline
\end{tabular}

Fonte: Autoria própria.

\section{RESULTADOS}

A tabela 1 corresponde ao total de documentos disponíveis na Plataforma JUSBRASIL obtidos por meio do descritor estruturado "evasão escolar". 
Tabela 1- Publicações aproveitadas para a Revisão Sistemática integrativa.

\begin{tabular}{|c|c|c|c|c|}
\hline $\begin{array}{c}\text { Descritor } \\
\text { estruturado }\end{array}$ & Bases de dados & $\begin{array}{c}\text { Total de publi- } \\
\text { cações sem o } \\
\text { filtro }\end{array}$ & $\begin{array}{c}\text { Publicações disponíveis } \\
\text { após aplicar os filtros }\end{array}$ & $\begin{array}{c}\text { Publicações } \\
\text { aproveitadas na } \\
\text { Revisão Siste- } \\
\text { mática Integra- } \\
\text { tiva }\end{array}$ \\
\hline Evasão escolar & $\begin{array}{l}\text { Plataforma JUS- } \\
\text { BRASIL }\end{array}$ & 21.773 & 172 & 29 \\
\hline
\end{tabular}

Fonte: Autoria própria

Foram detectadas 21.773 publicações científicas nos bancos de dados, das quais 172 eram artigos de opinião disponíveis após o uso dos filtros, desses foram analisados 29 artigos, que obedeceram aos critérios de inclusão (Tabela 1), sendo submetidos às etapas da pesquisa documental
(Figura 3). Quanto ao ano de publicação, três estudos foram publicados no ano de 2019; dez estudos foram publicados no ano de 2018; um, no ano de 2017; dez, em 2016; quatro, em 2015 e um, em 2014, o que evidencia a atualidade do tema. 


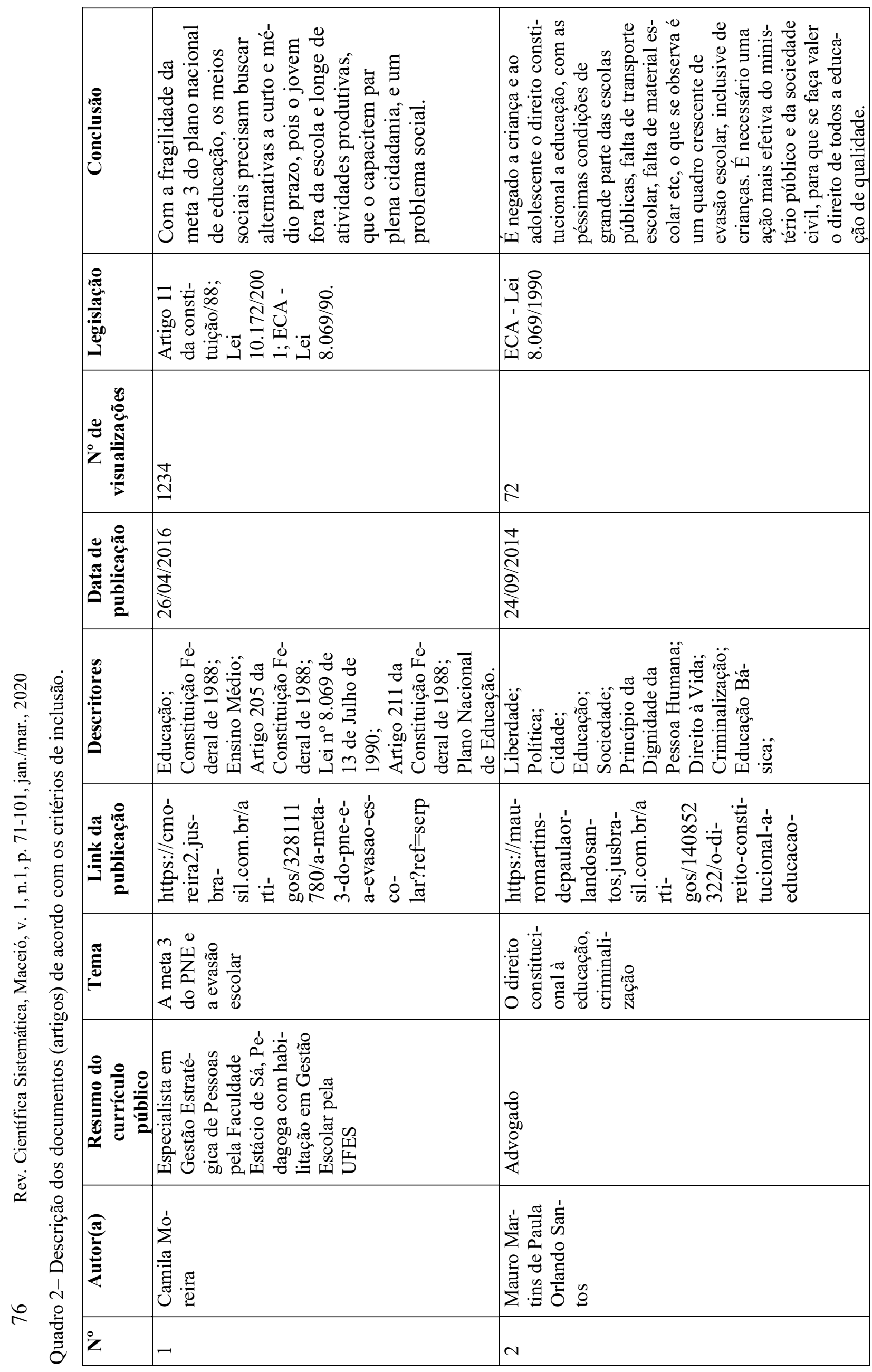




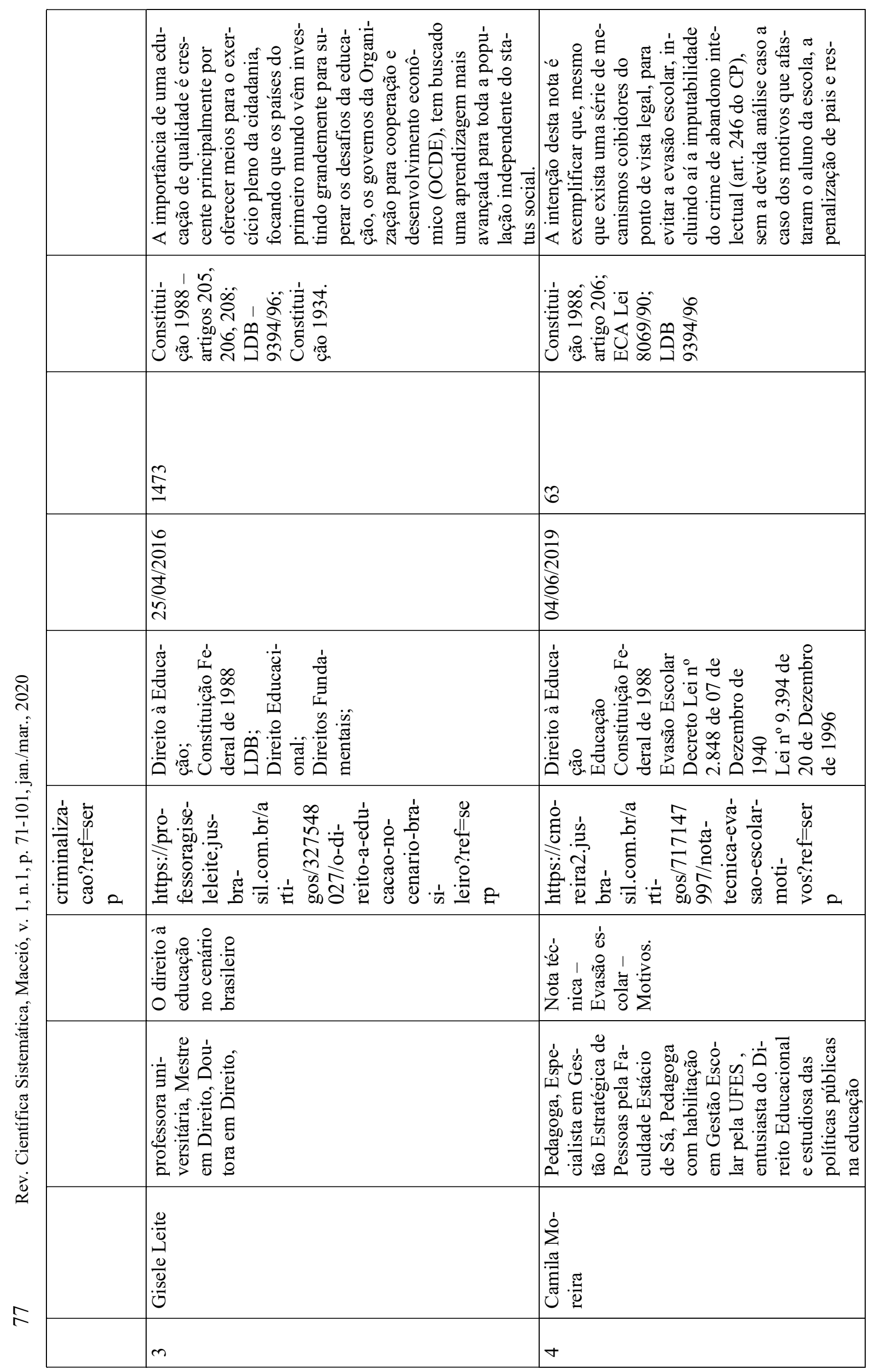




\begin{tabular}{|c|c|c|}
\hline \multicolumn{2}{|r|}{ 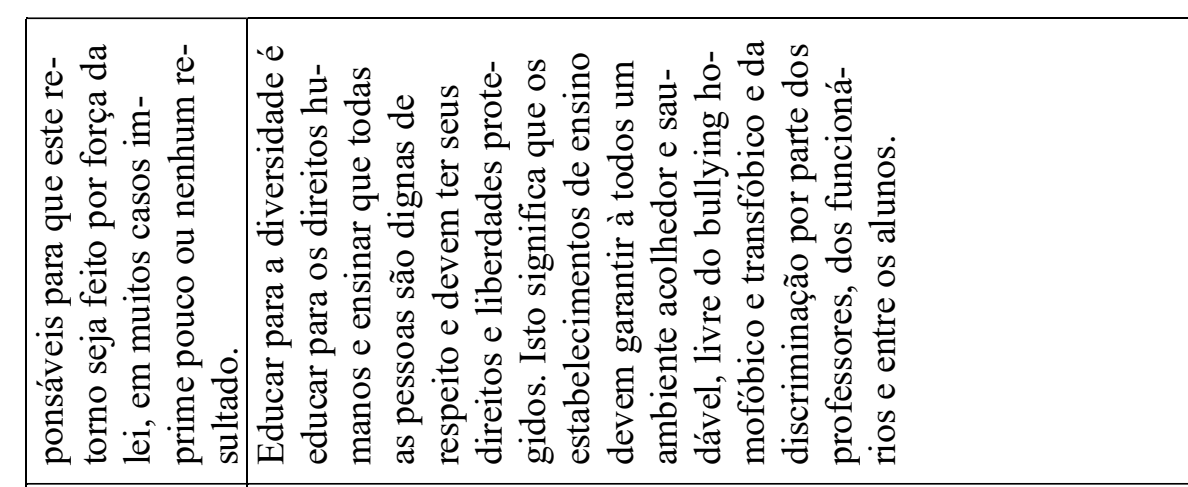 } & 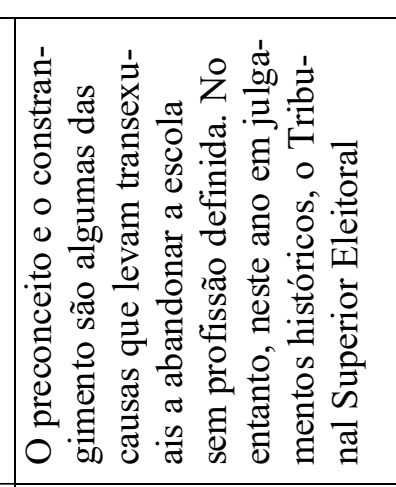 \\
\hline & 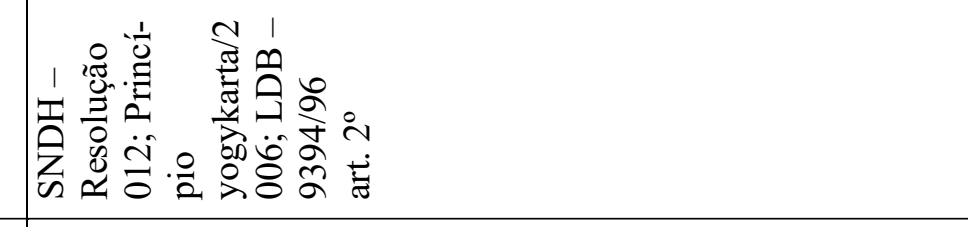 & 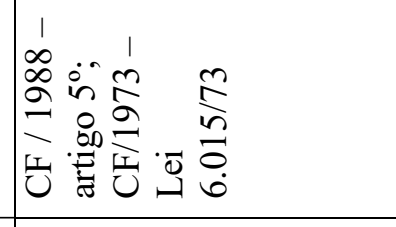 \\
\hline & $\cong$ & $\stackrel{0}{i}$ \\
\hline & 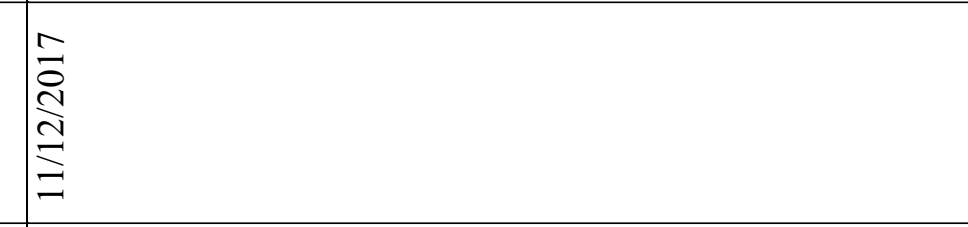 & 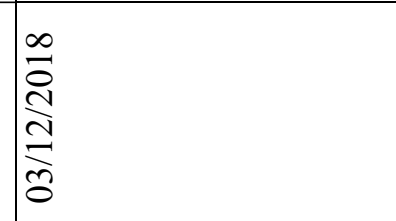 \\
\hline 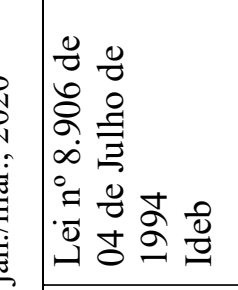 & 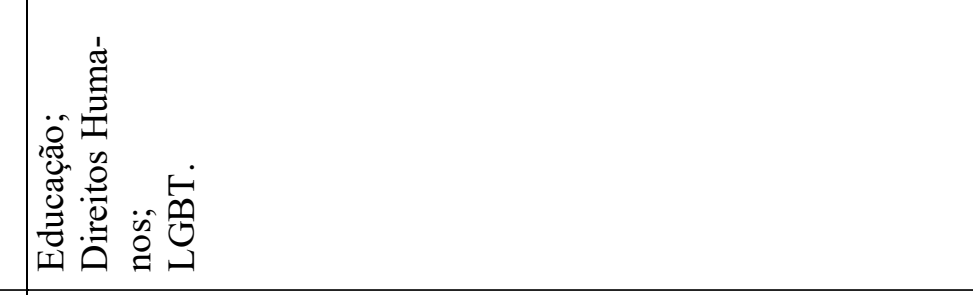 & 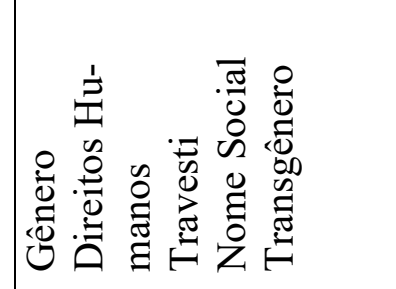 \\
\hline & 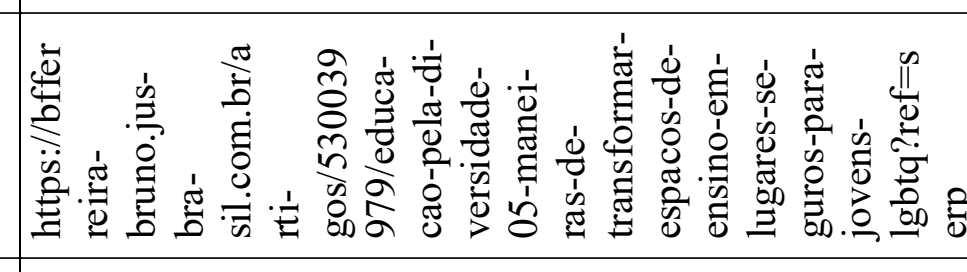 & 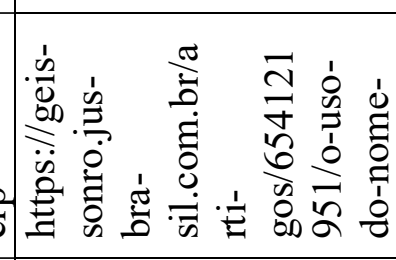 \\
\hline & 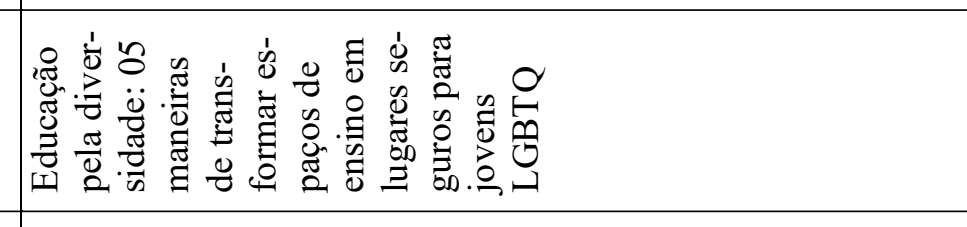 & 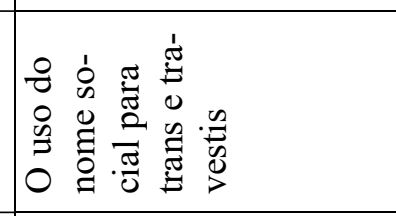 \\
\hline & 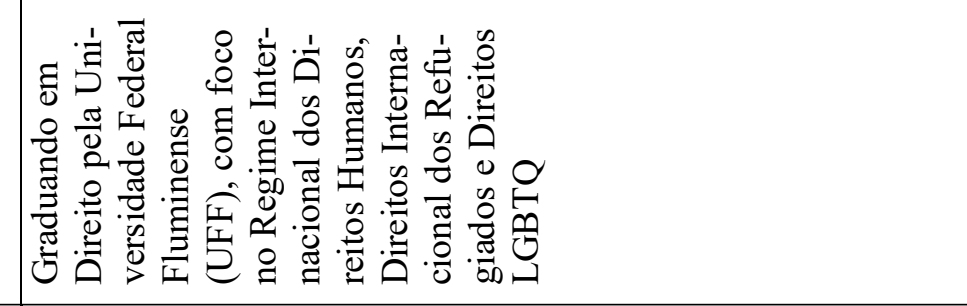 & 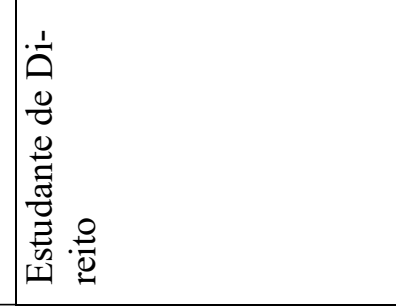 \\
\hline & 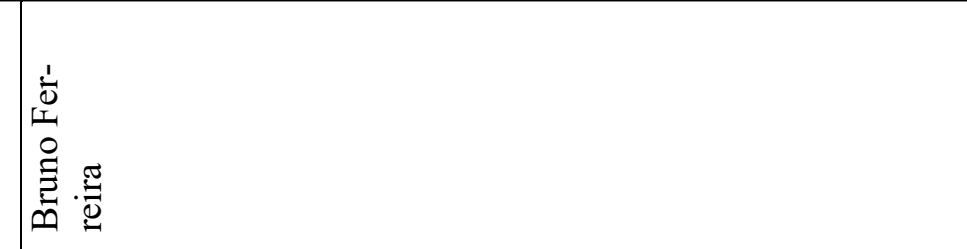 & 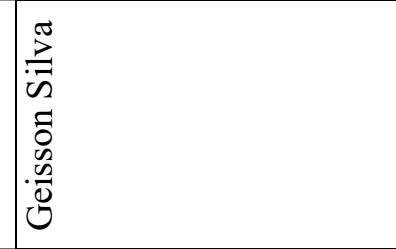 \\
\hline & in & o \\
\hline
\end{tabular}




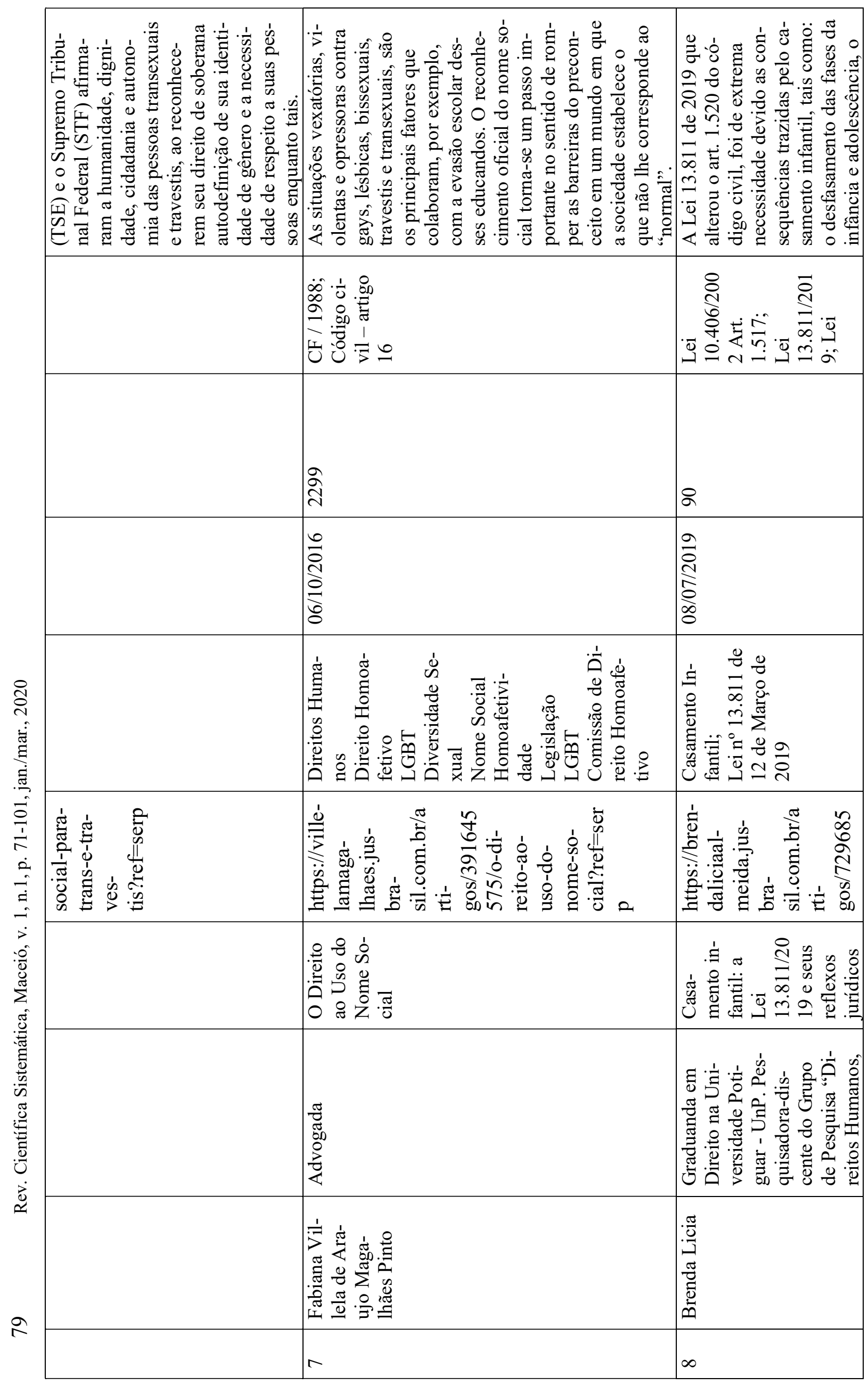




\begin{tabular}{|c|c|c|}
\hline & 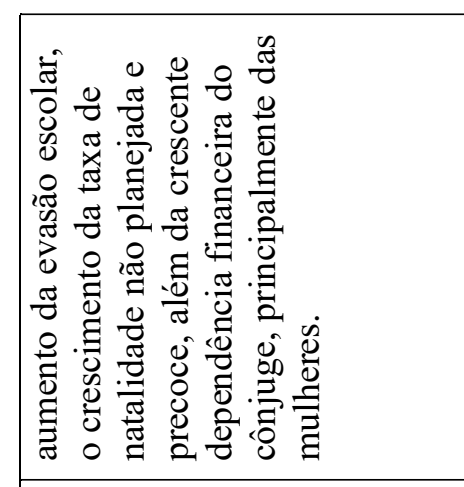 & 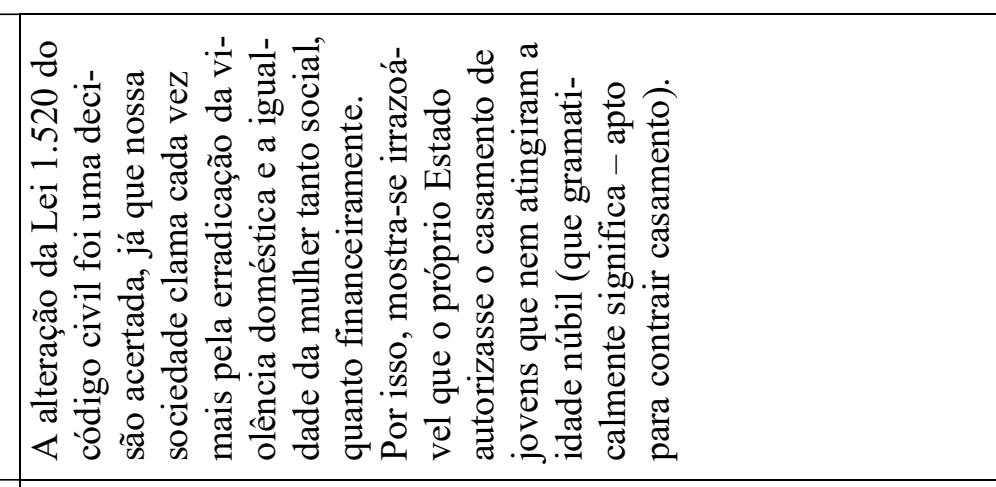 \\
\hline & 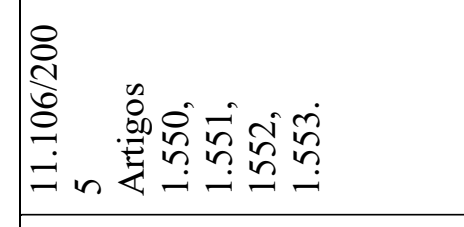 & 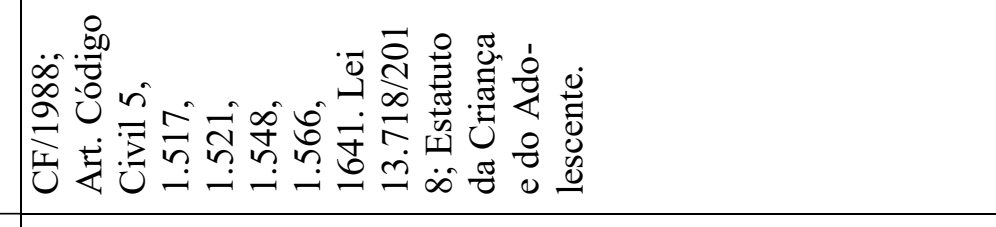 \\
\hline & & ఏ్ \\
\hline & & 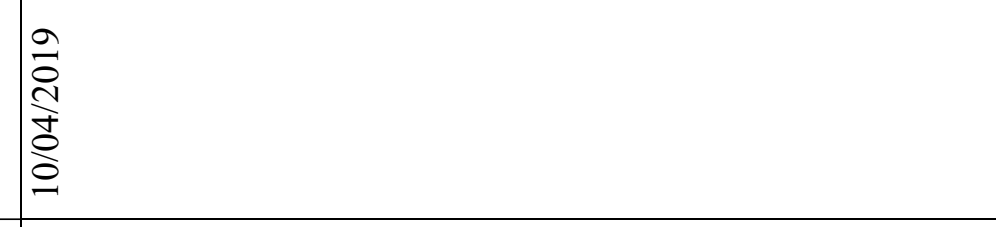 \\
\hline & & 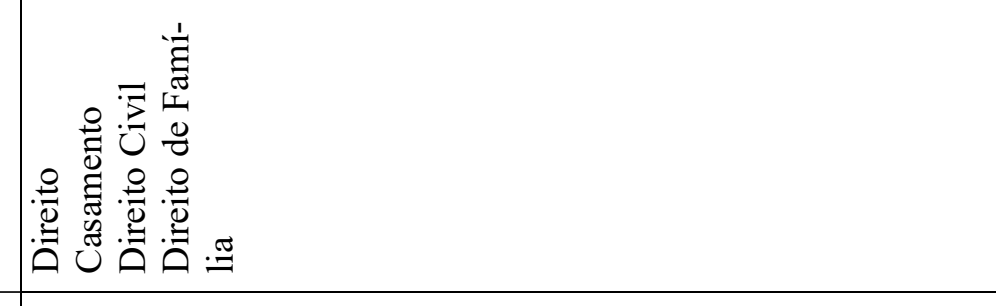 \\
\hline & 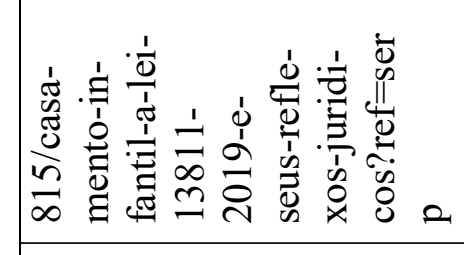 & 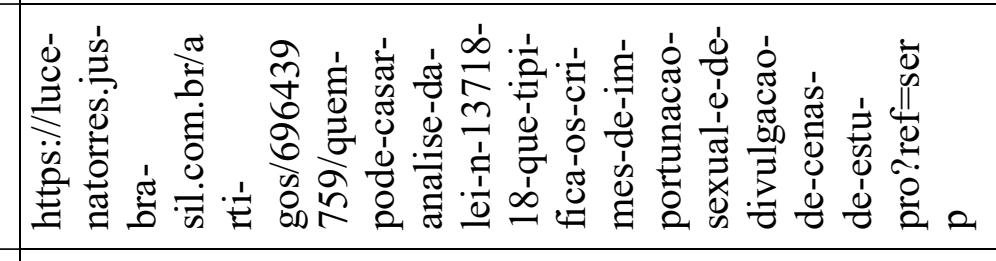 \\
\hline & & 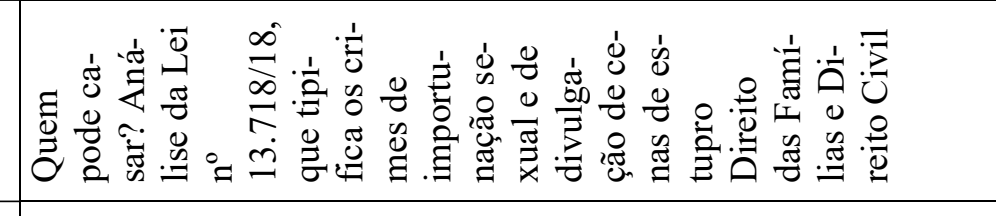 \\
\hline & 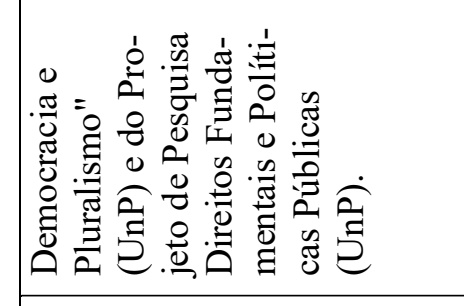 & 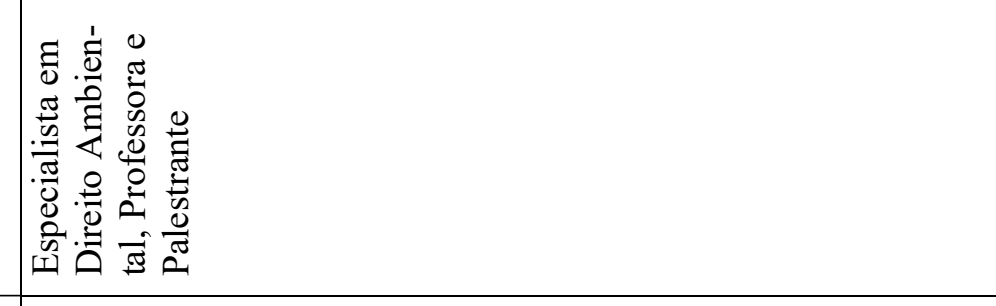 \\
\hline & & 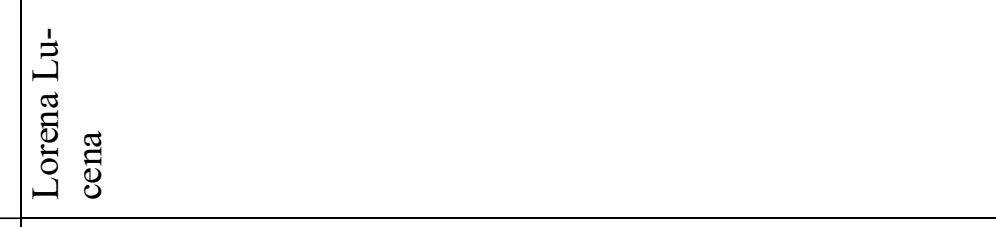 \\
\hline & & a \\
\hline
\end{tabular}




\begin{tabular}{|c|c|c|}
\hline 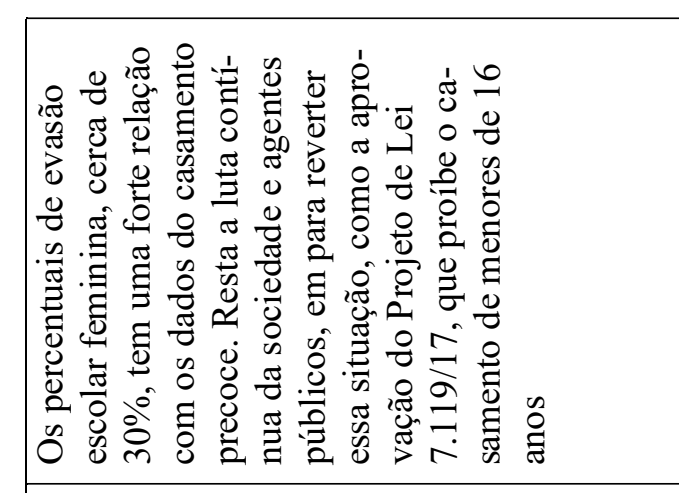 & 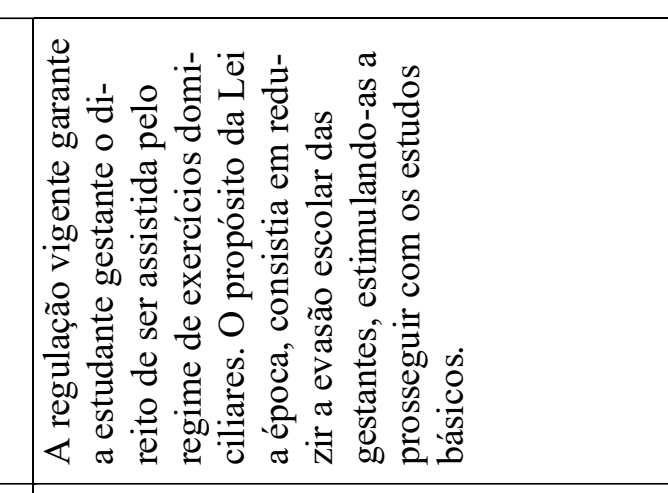 & 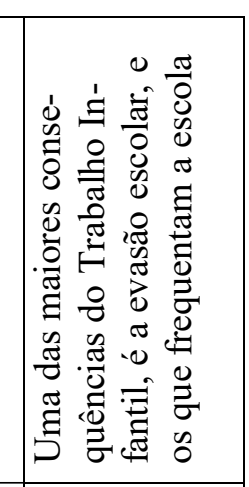 \\
\hline 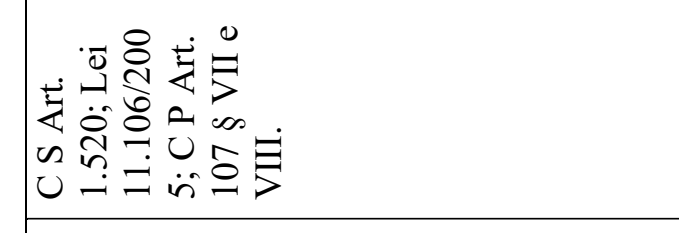 & 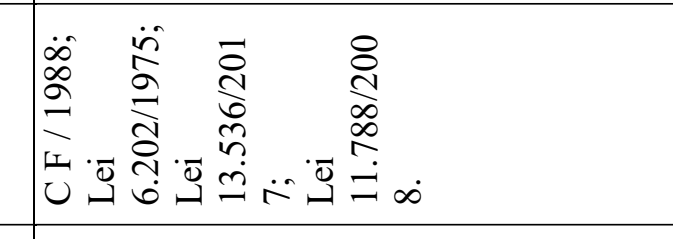 & 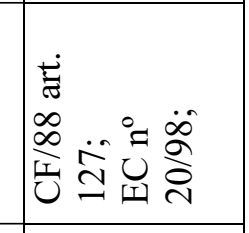 \\
\hline 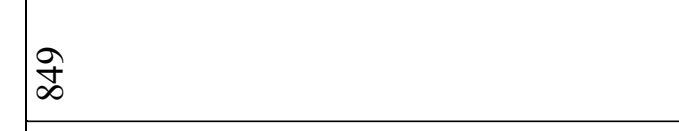 & 总 & î \\
\hline 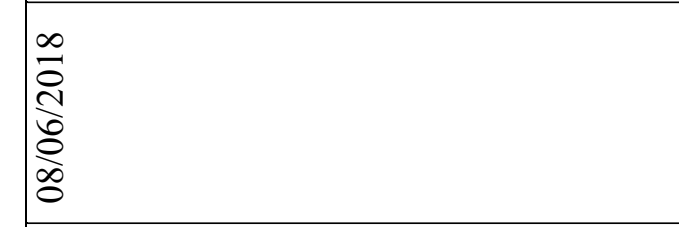 & 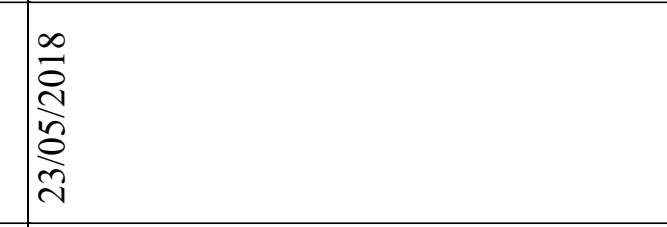 & 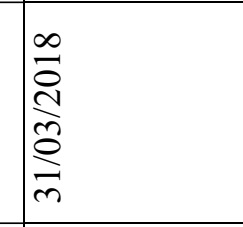 \\
\hline 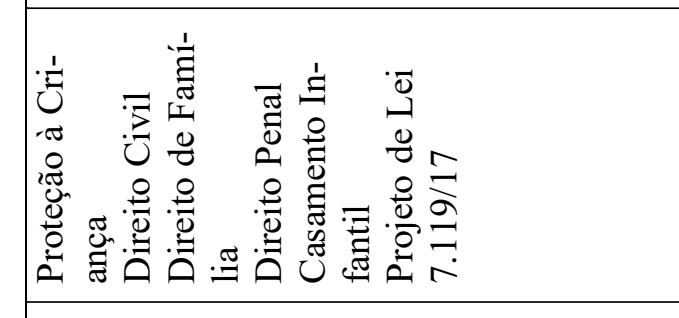 & 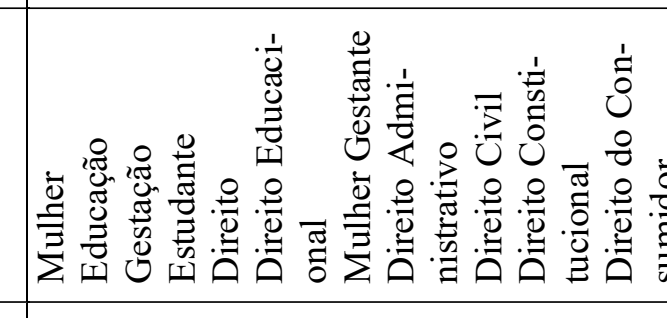 & 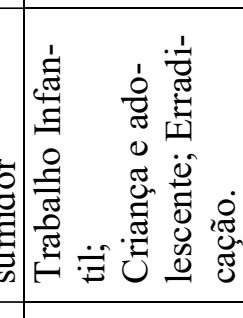 \\
\hline 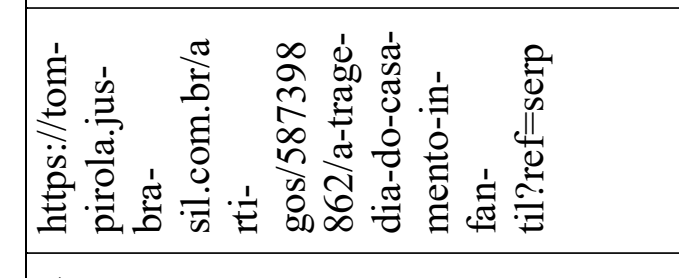 & 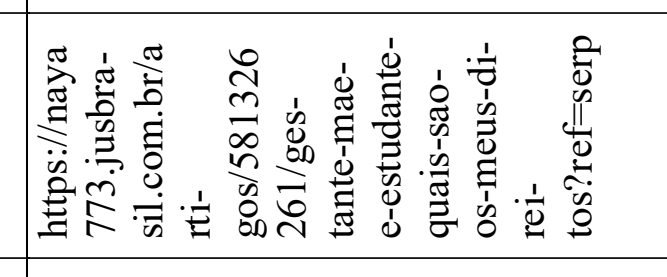 & 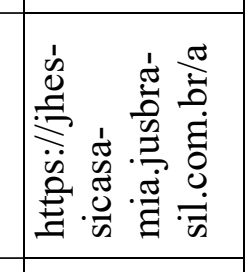 \\
\hline 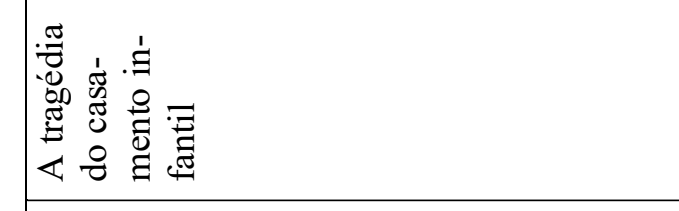 & 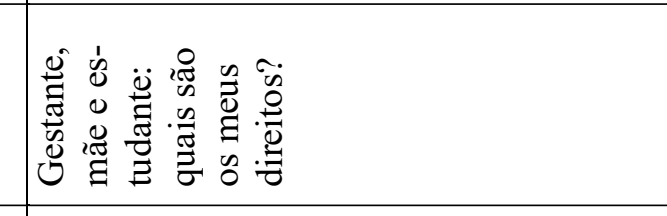 & 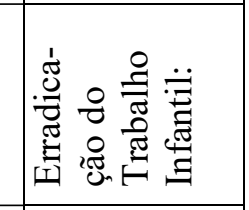 \\
\hline 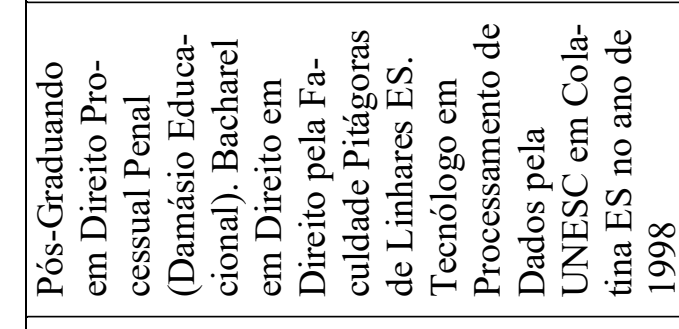 & 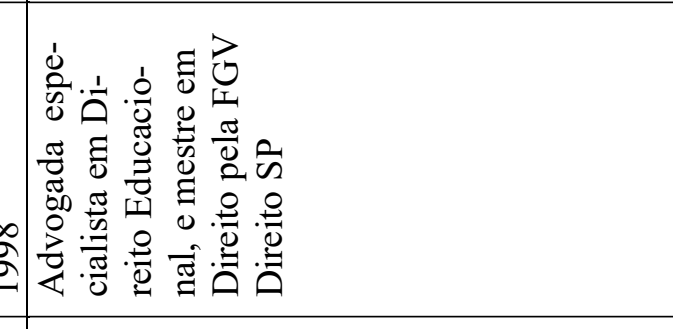 & 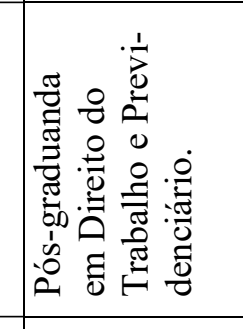 \\
\hline 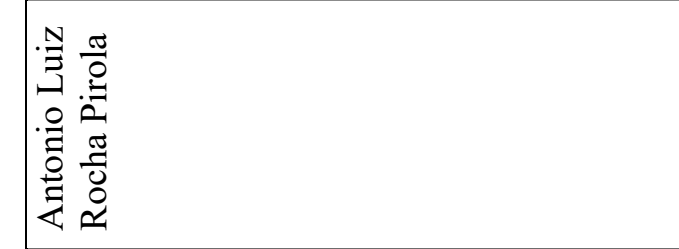 & 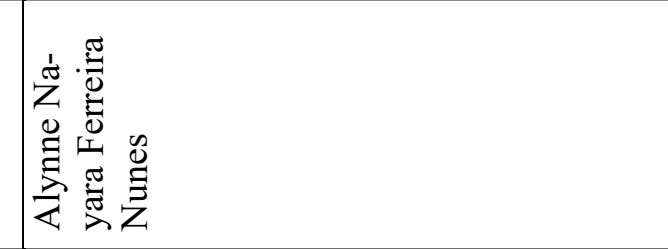 & 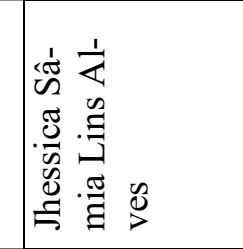 \\
\hline$\varrho$ & $=$ & $\simeq$ \\
\hline
\end{tabular}




\begin{tabular}{|c|c|c|}
\hline 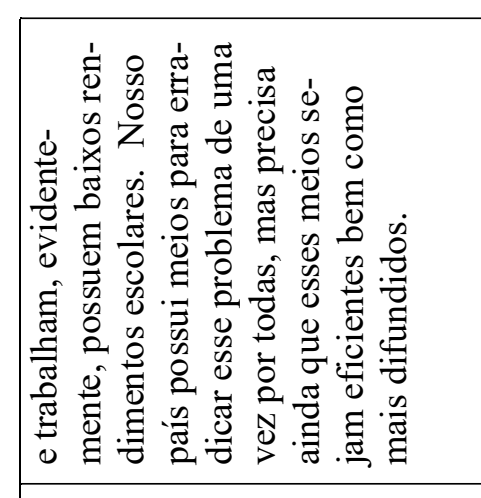 & 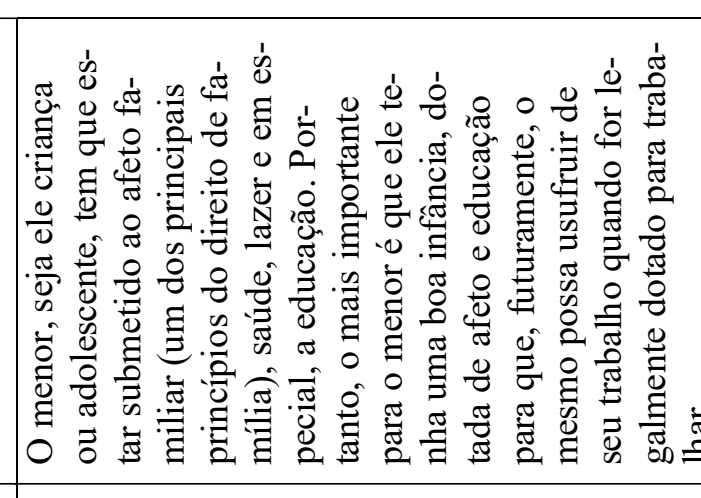 & 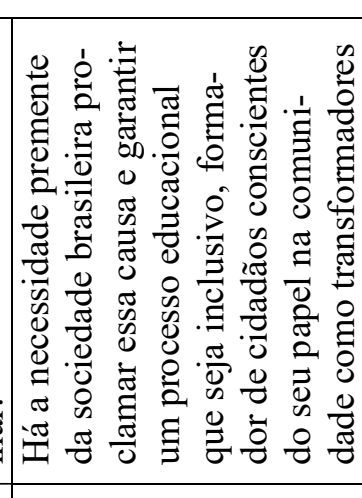 \\
\hline 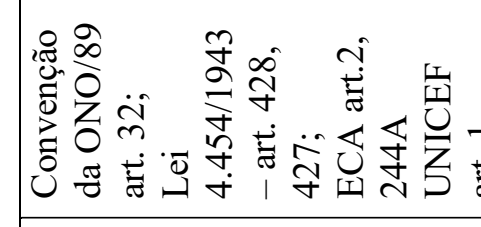 & 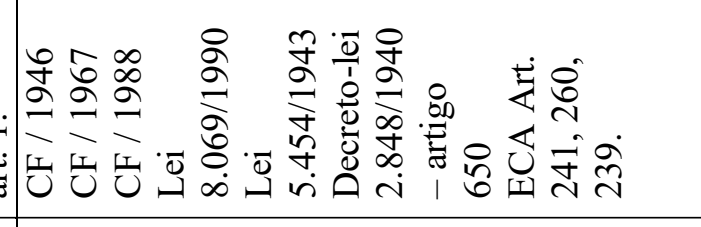 & 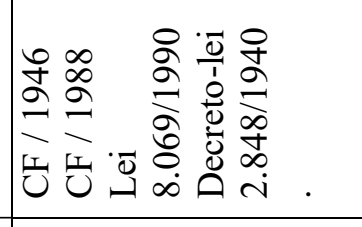 \\
\hline & 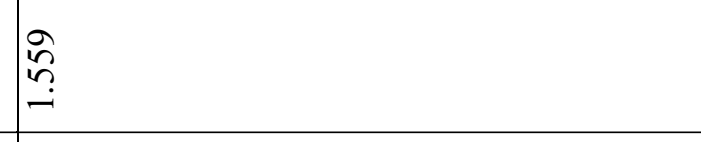 & $\overrightarrow{\mathrm{d}}$ \\
\hline & 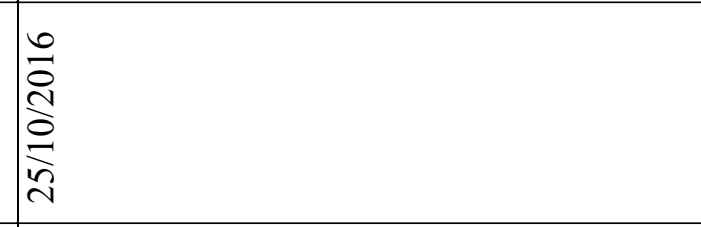 & 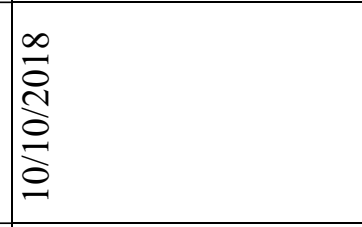 \\
\hline & 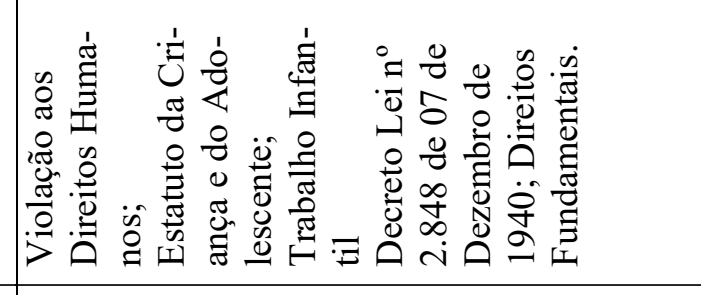 & 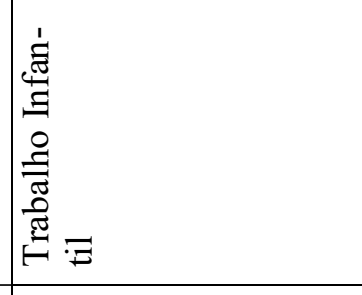 \\
\hline 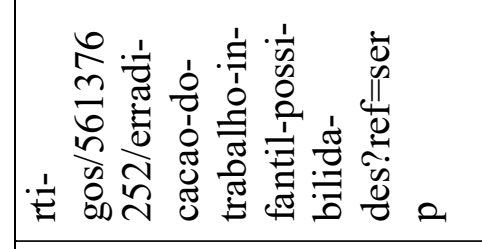 & 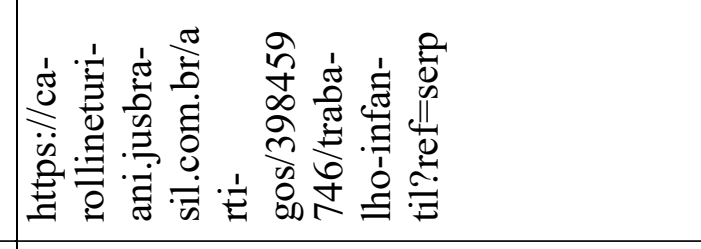 & 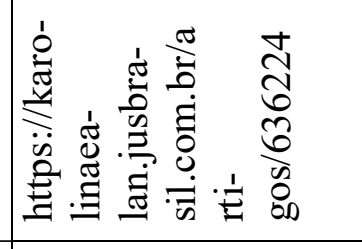 \\
\hline 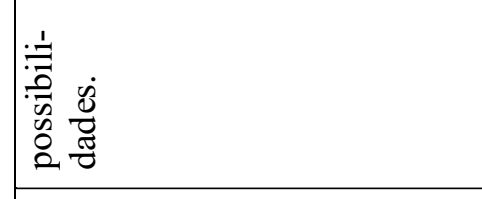 & 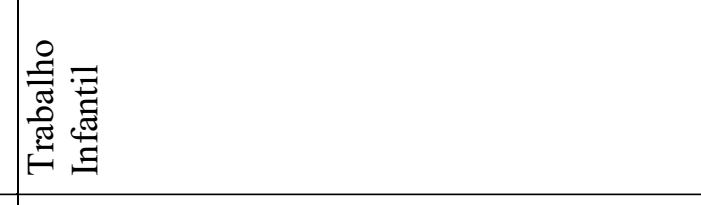 & 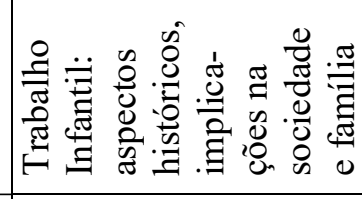 \\
\hline & 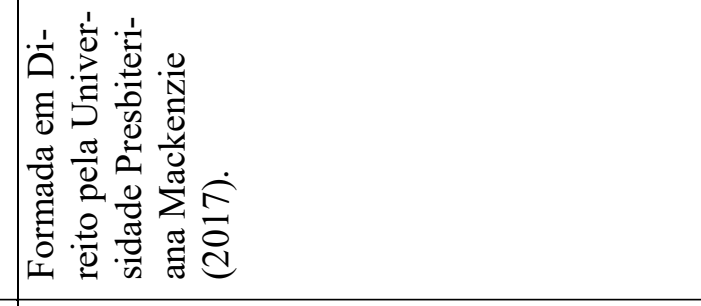 & 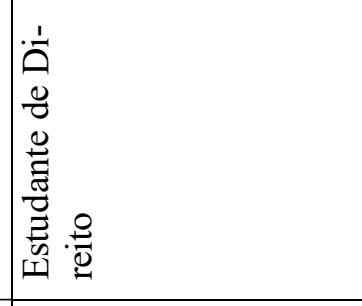 \\
\hline & 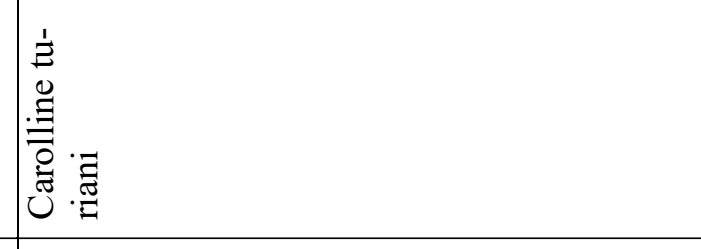 & 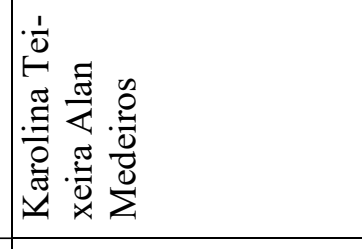 \\
\hline & $\cong$ & \pm \\
\hline
\end{tabular}




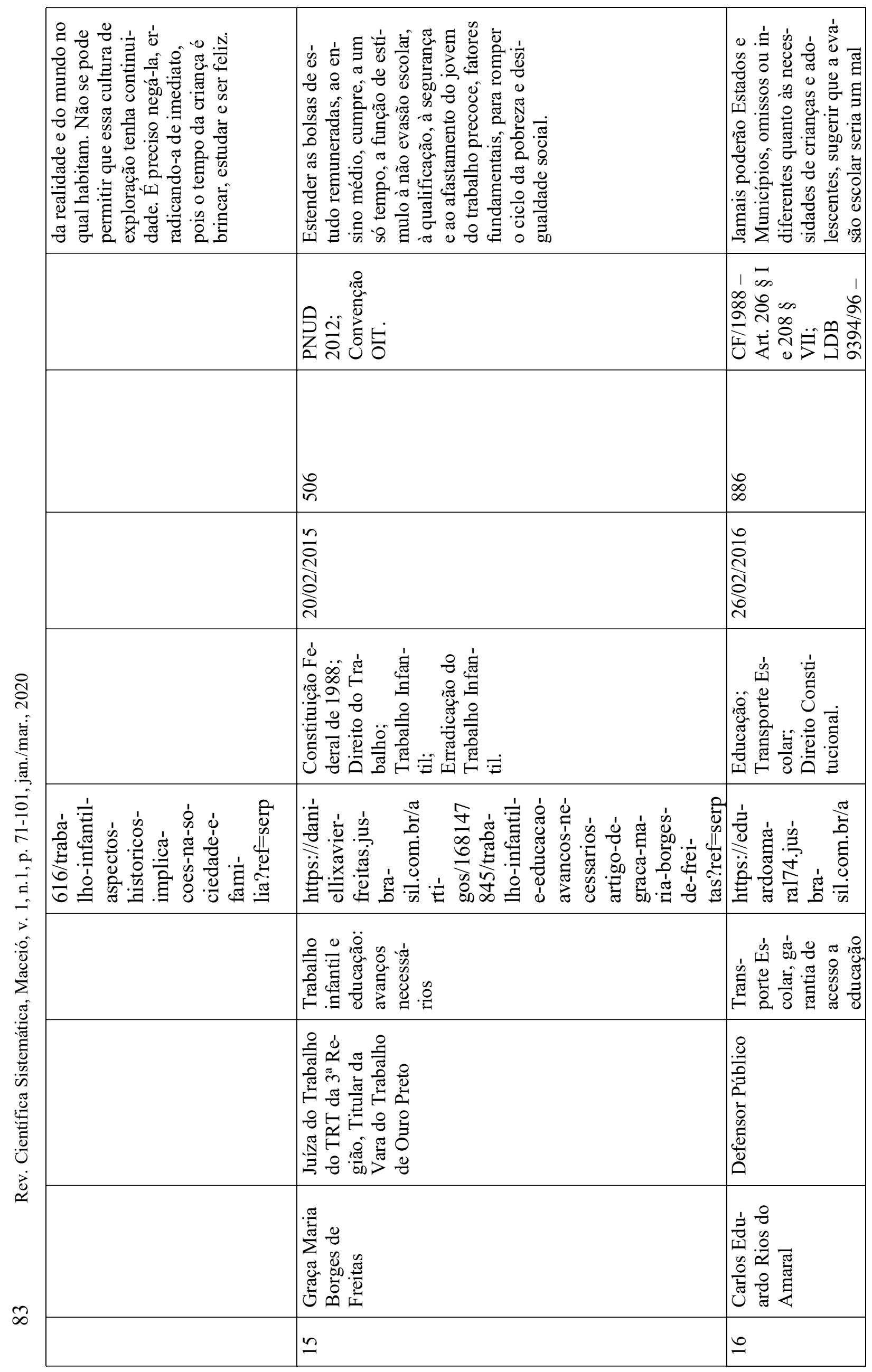

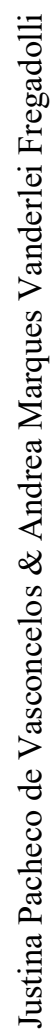




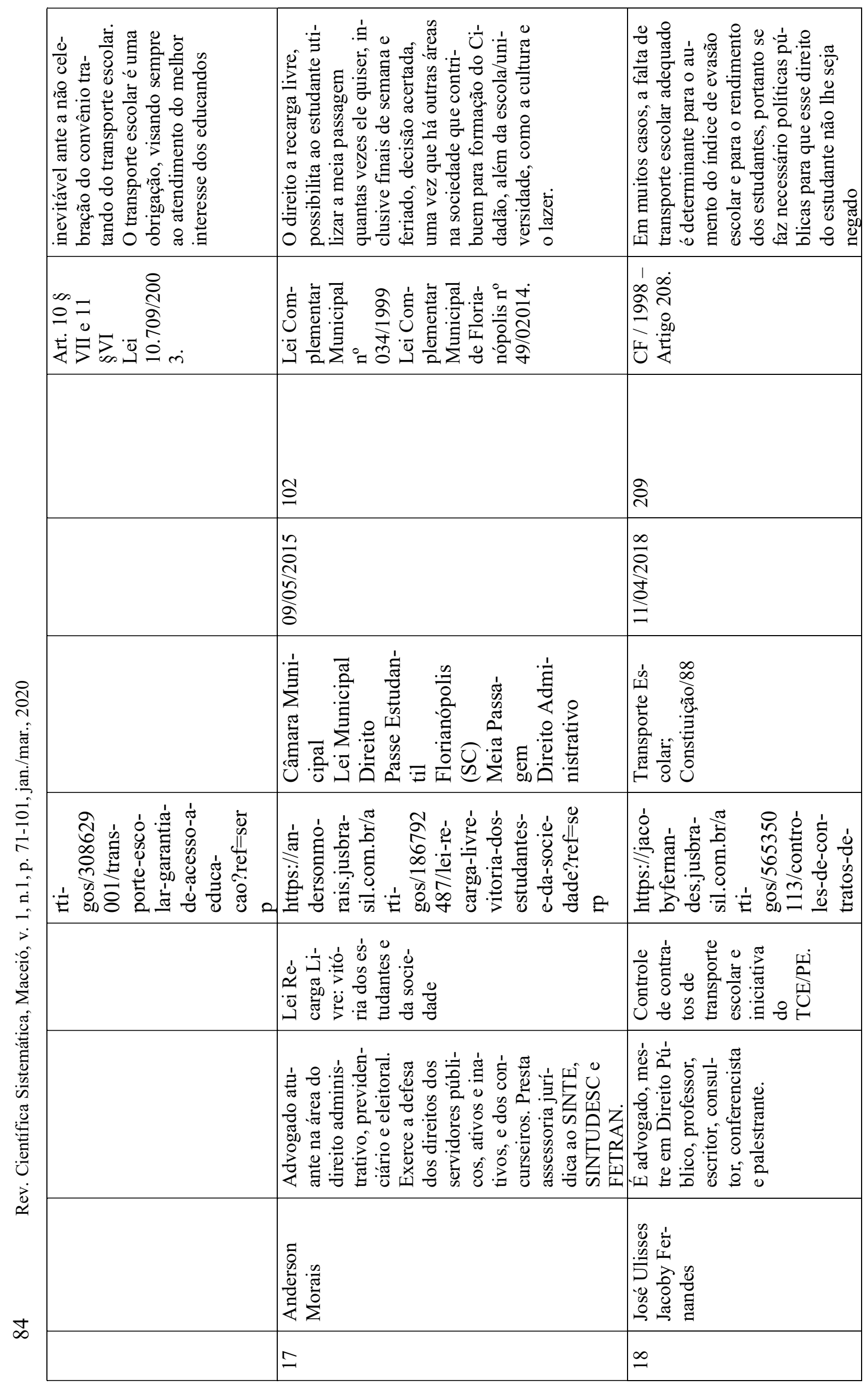




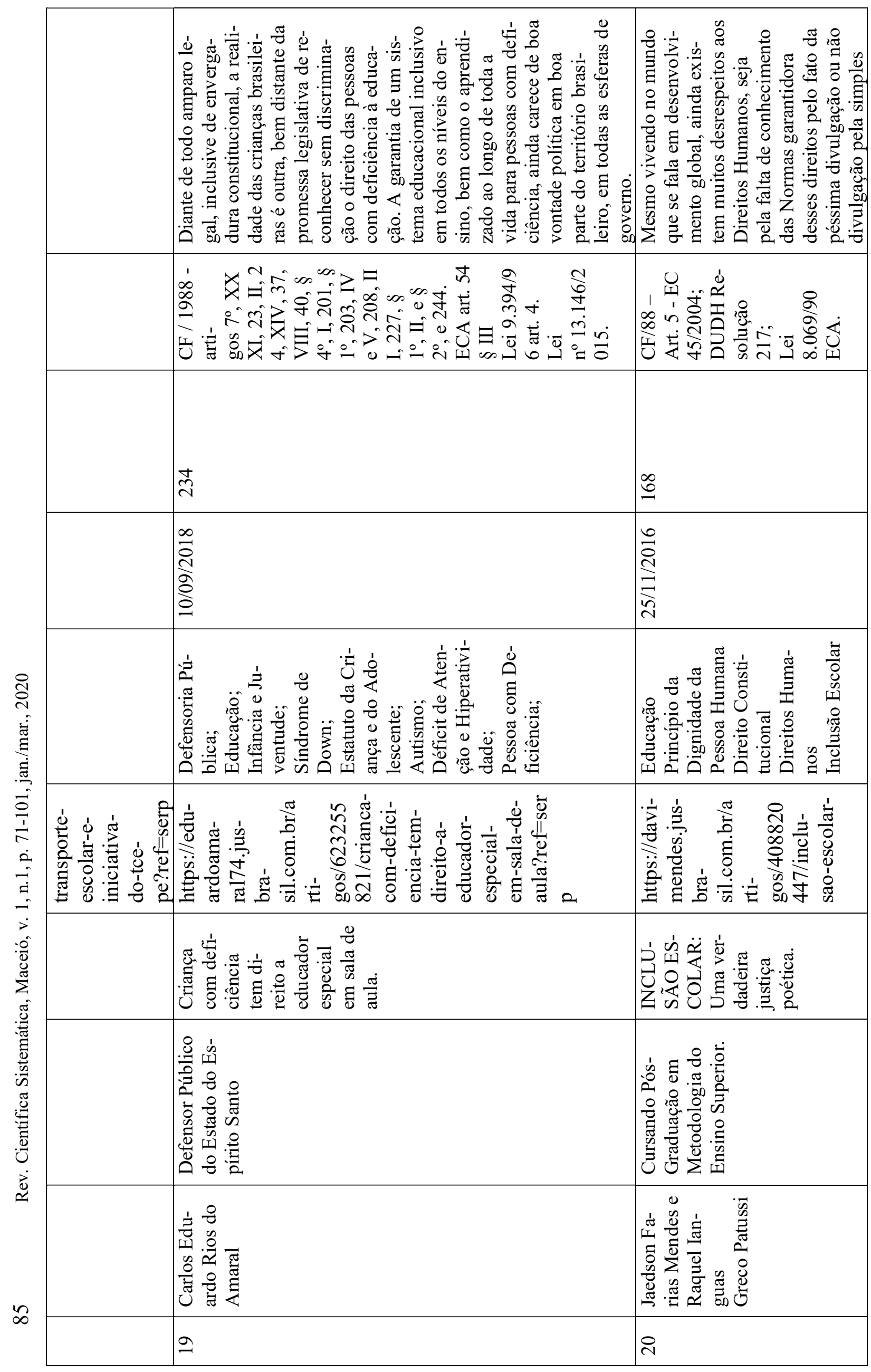




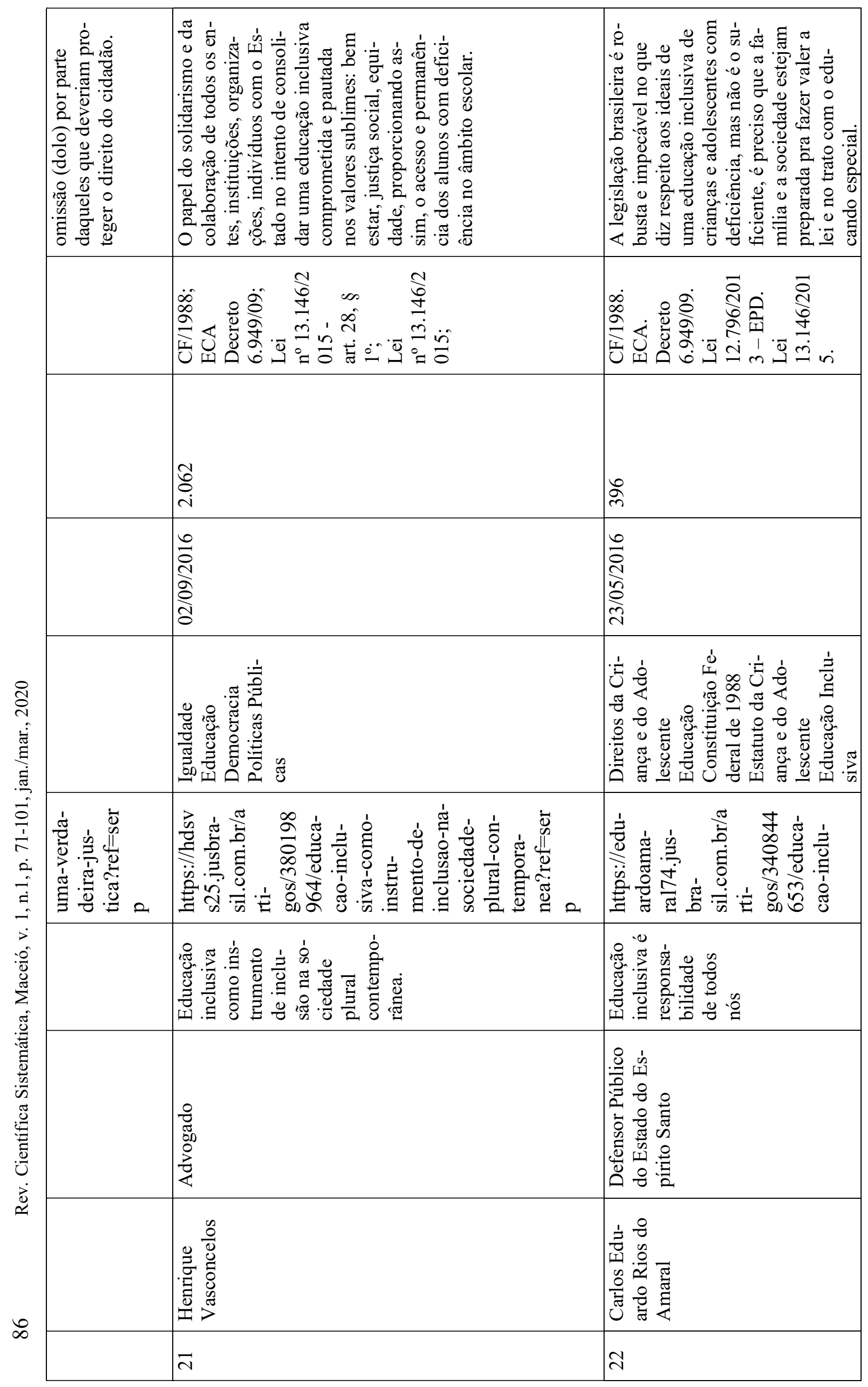

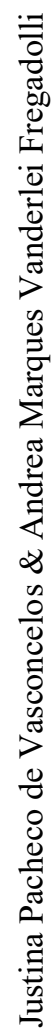




\begin{tabular}{|c|c|c|}
\hline & 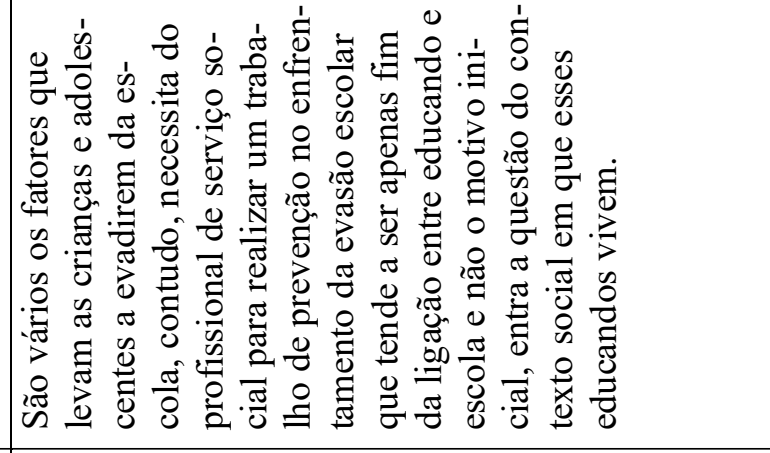 & 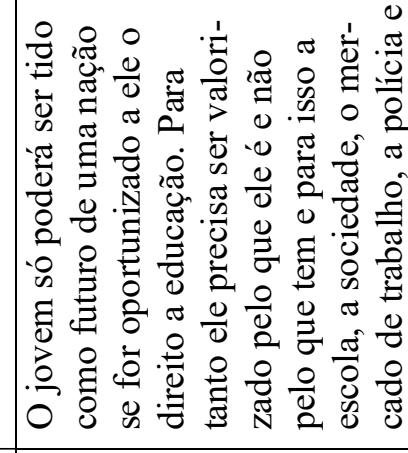 \\
\hline & 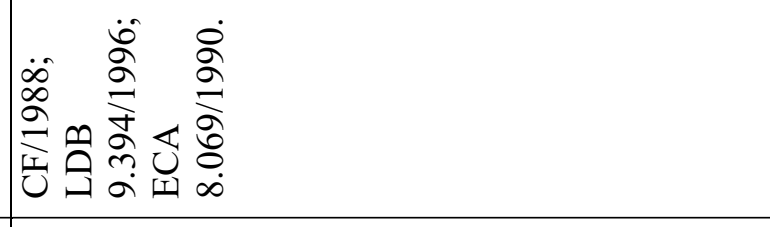 & 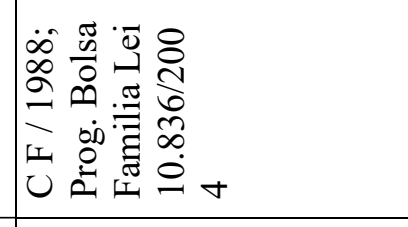 \\
\hline & $\approx$ & 雚 \\
\hline & 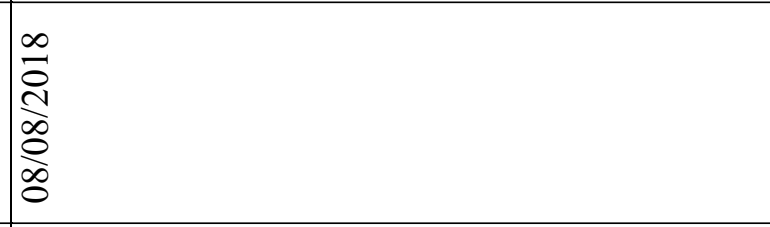 & 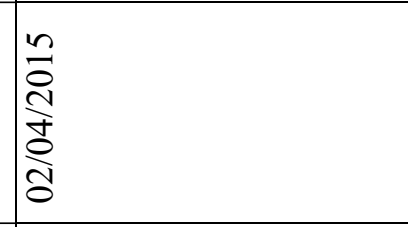 \\
\hline & 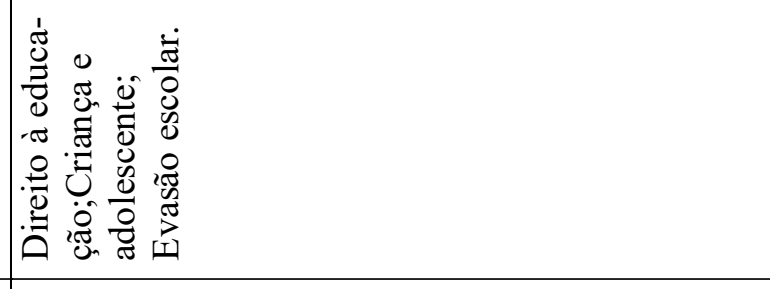 & 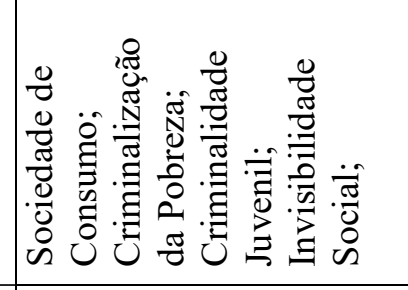 \\
\hline 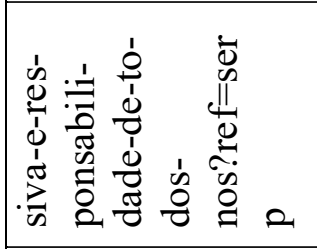 & 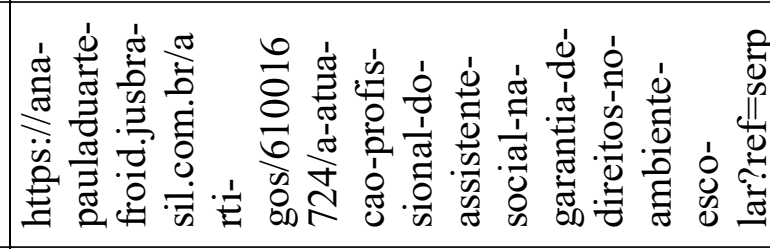 & 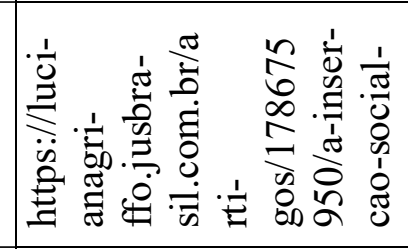 \\
\hline & 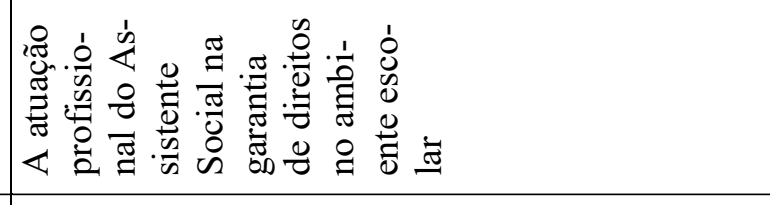 & 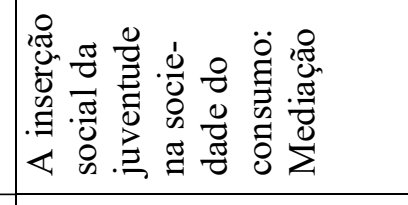 \\
\hline & 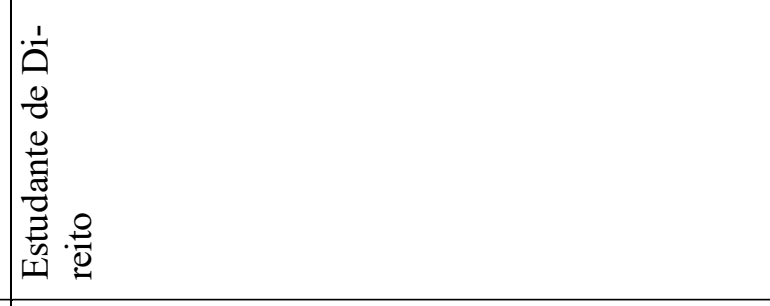 & 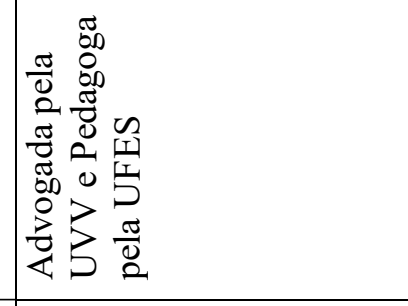 \\
\hline & 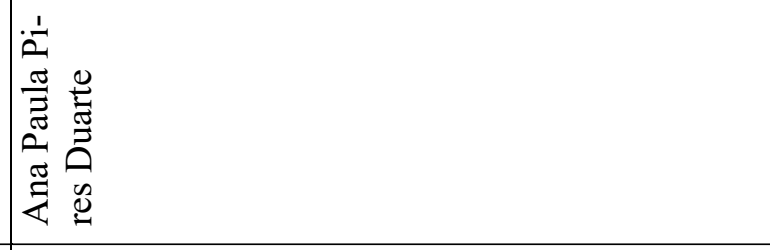 & 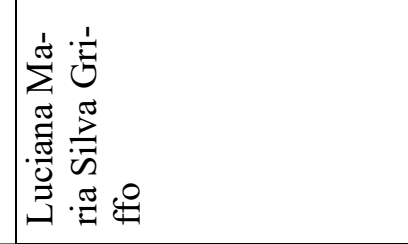 \\
\hline & $\approx$ & I \\
\hline
\end{tabular}




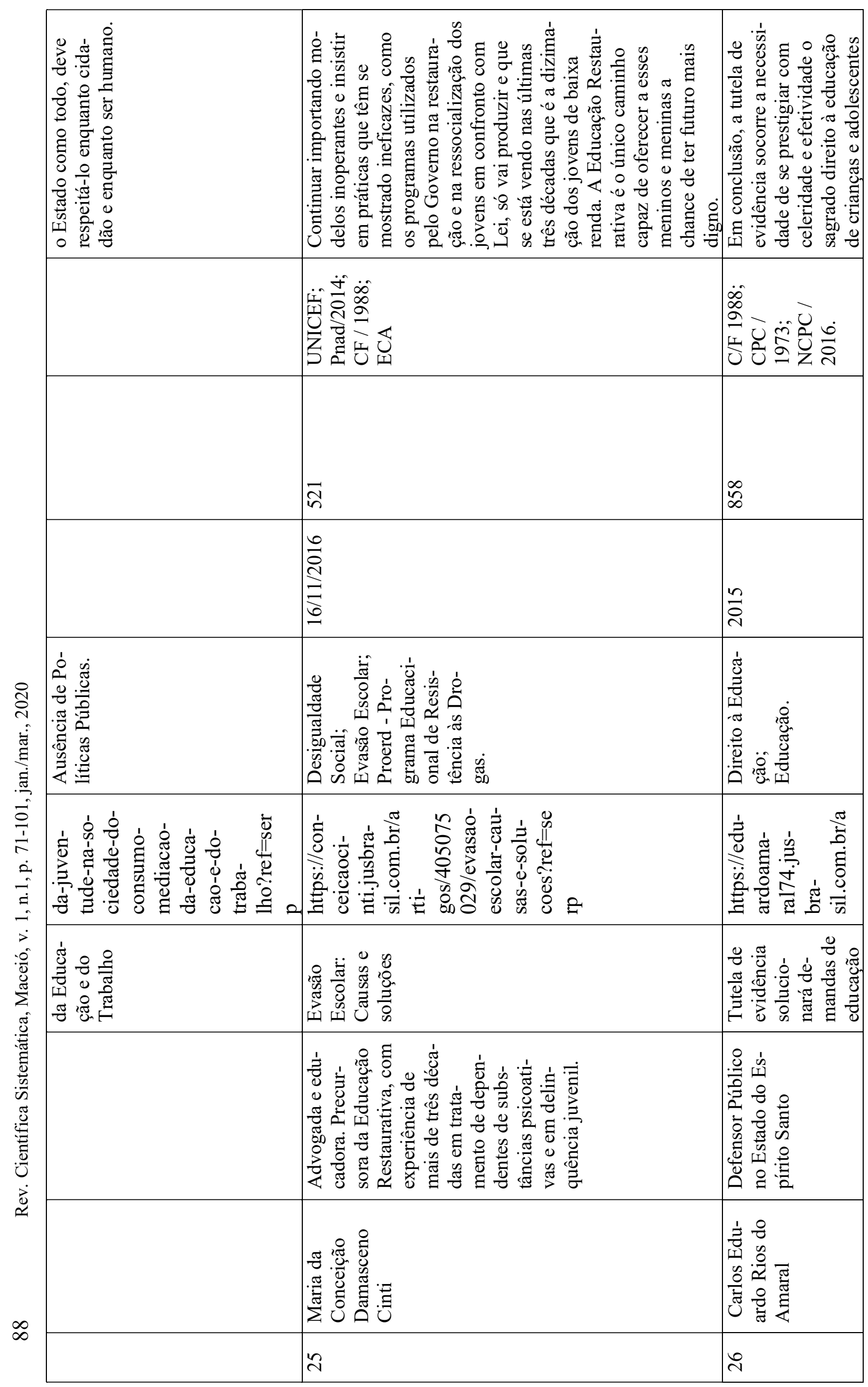




\begin{tabular}{|c|c|c|c|}
\hline & 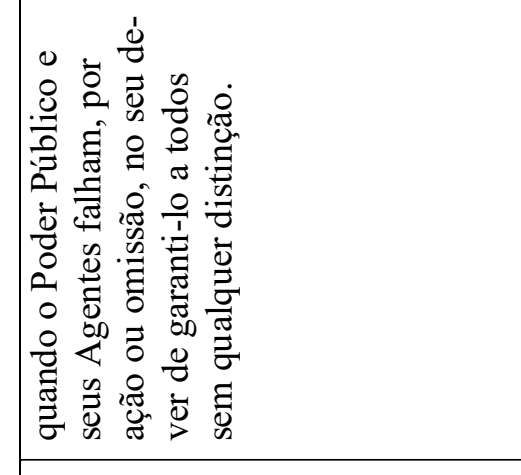 & 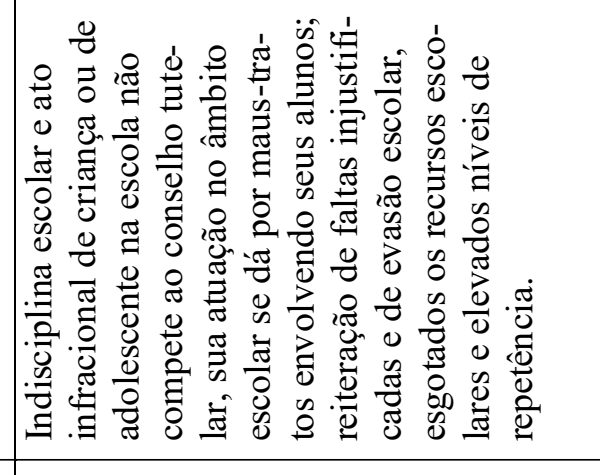 & 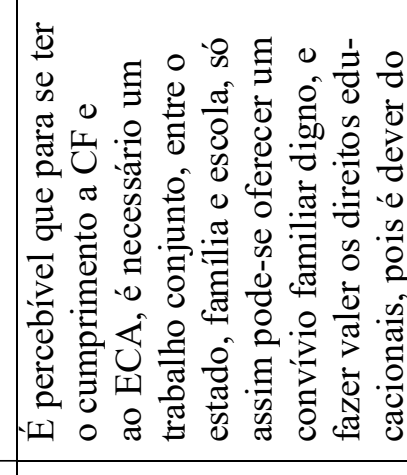 \\
\hline \multirow{4}{*}{\multicolumn{2}{|c|}{ 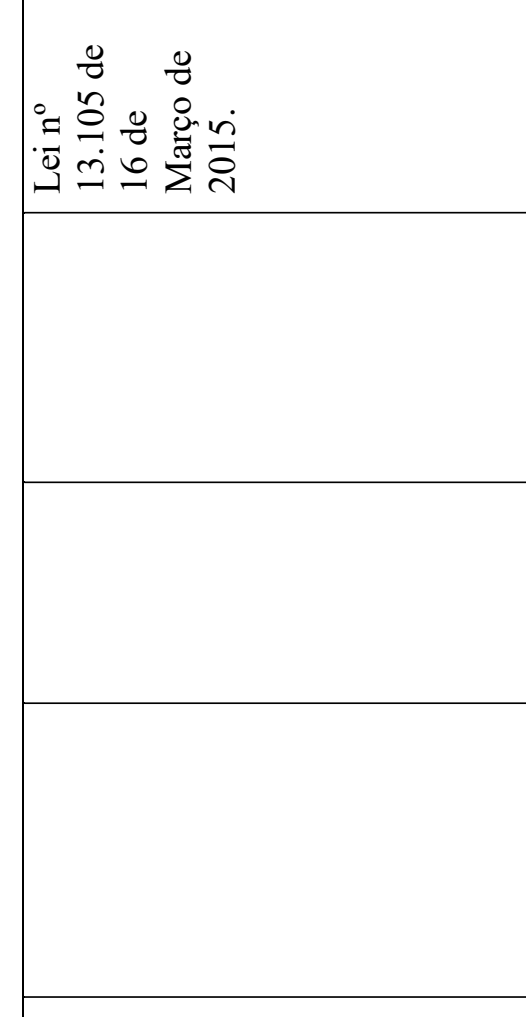 }} & 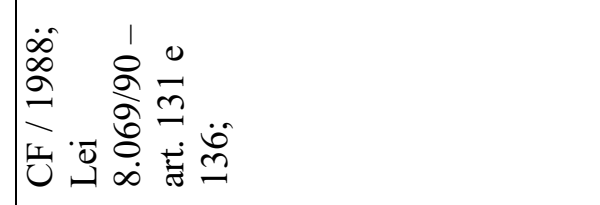 & 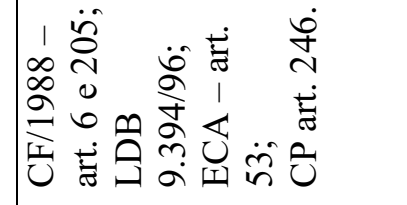 \\
\hline & & 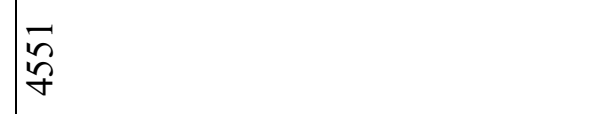 & $\Xi$ \\
\hline & & 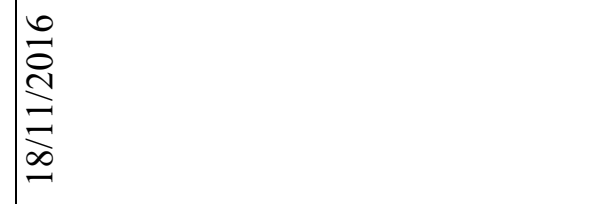 & 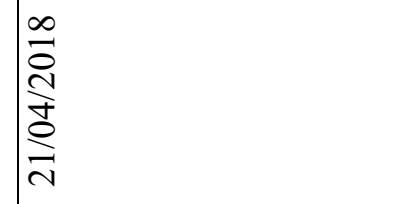 \\
\hline & & 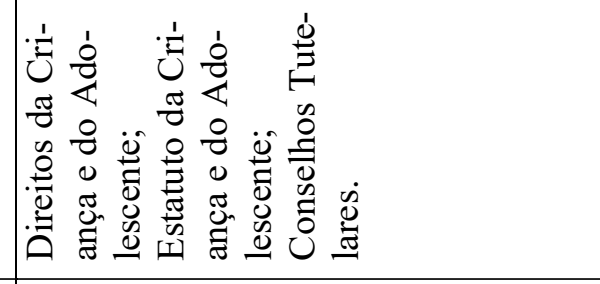 & 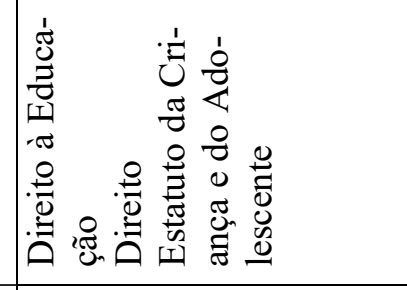 \\
\hline & 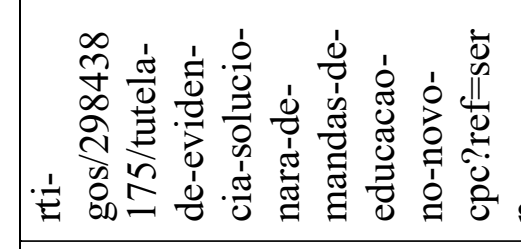 & 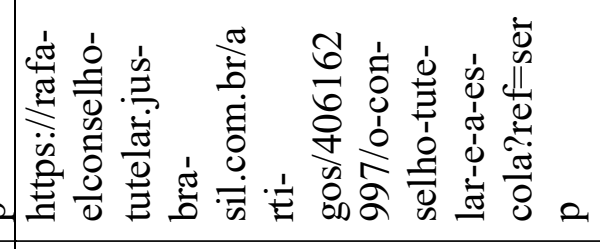 & 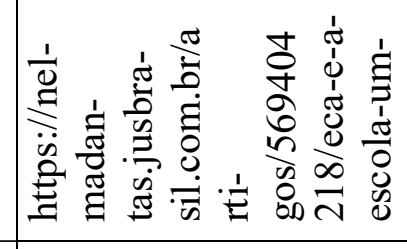 \\
\hline \multirow{3}{*}{\multicolumn{2}{|c|}{$\begin{array}{l}0 \\
\vdots \\
\vdots \\
0 \\
\vdots \\
0\end{array}$}} & 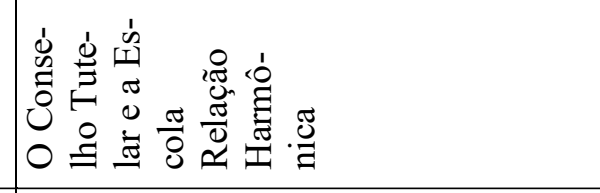 & 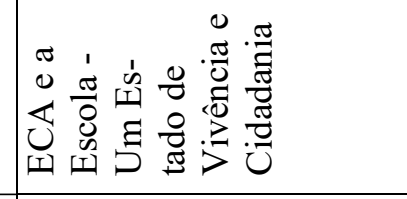 \\
\hline & & 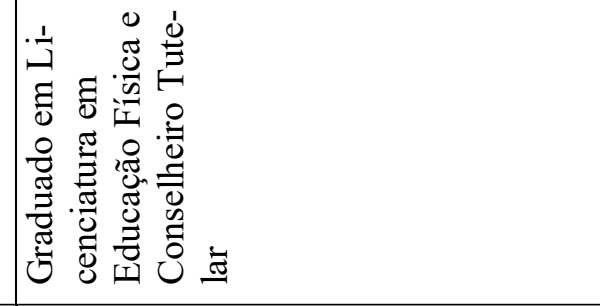 & 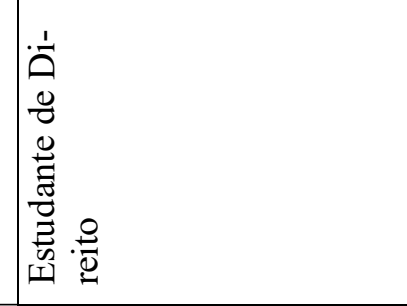 \\
\hline & & 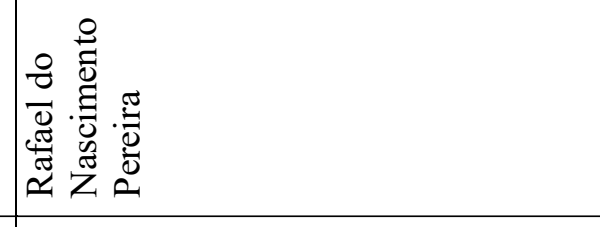 & 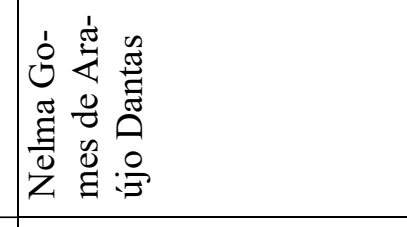 \\
\hline & & $\hat{\lambda}$ & $\underset{\sim}{\infty}$ \\
\hline
\end{tabular}




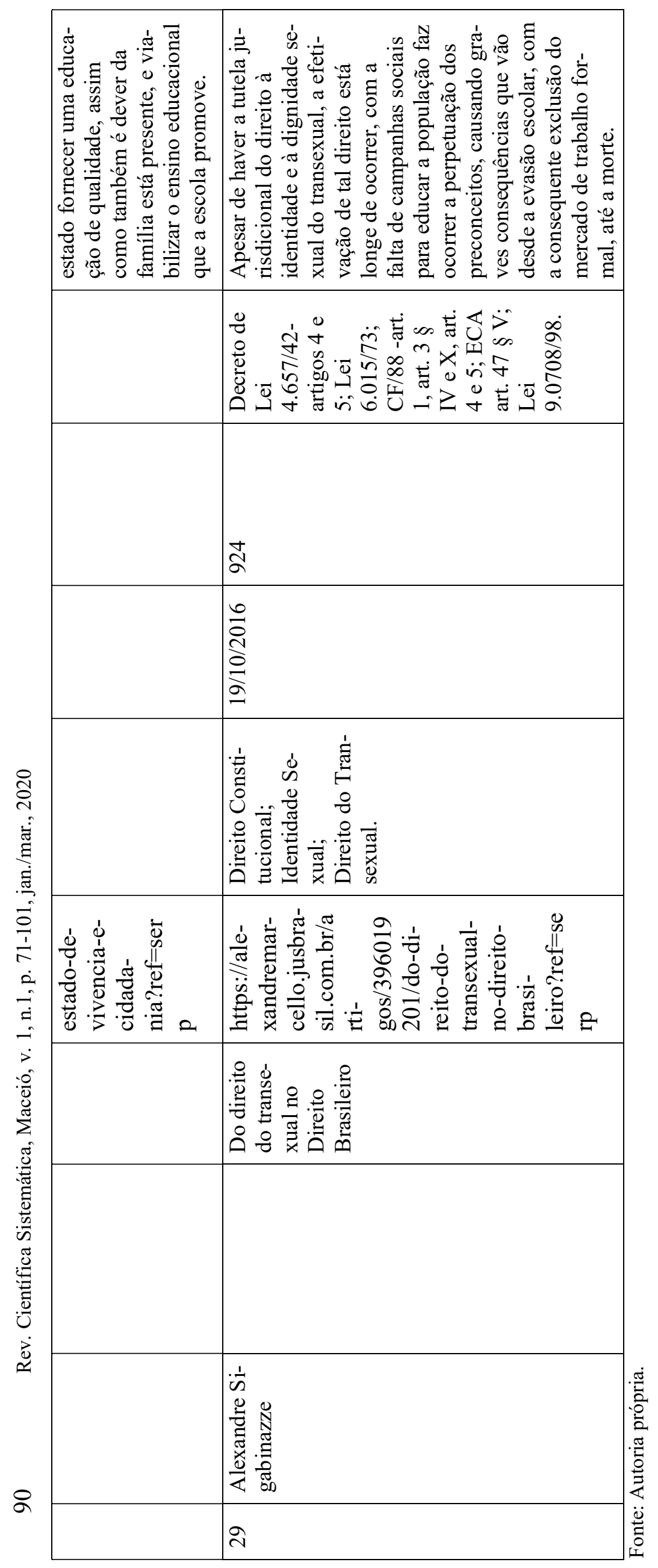

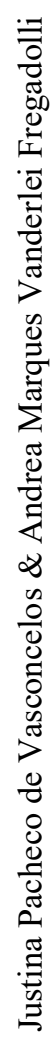




\section{DISCUSSÃO}

O povo brasileiro tem direito a educação de qualidade garantido pela nossa constituição, no entanto, sabe-se que essa realidade ainda está longe de acontecer, talvez por uma garantia tardia, pois a constituição só foi promulgada em 1988, como também pela falta de uma ação pública que priorize e tenha como meta a educação para todos. No Brasil, o direito a educação, parte ainda é negligenciado e a consequência disso é o fracasso educacional na rede pública.

Seguem abaixo, as categorias temáticas elaboradas a partir da revisão sistemática integrativa.

\section{Garantias do direito ao acesso à educação de qualidade a todos.}

Esta categoria integrou a discussão de oito artigos relacionados com o direito a educação garantidos constitucionalmente a todos.

A constituição de 1934 foi a primeira a ter um capítulo exclusivo para educação. Com a ditadura do Estado Novo (1937-1845) retirou-se a obrigatoriedade do Estado quanto à educação, criando um sistema dual, em que as escolas diferenciadas eram destinadas às elites e às classes trabalhadoras. No Brasil, a dificuldade de escolarização e o sucesso acadêmico foram permeados por inúmeras variáveis parado- xais, que incluem desde a formação do professor até as condições econômicas brasileiras (LEITE 2016).

Moreira (2019) cita que o direito à educação da criança e do adolescente está garantido pela Constituição Federal de 1988 e demais adequação da legislação como LDB, ECA, entre outros. A Constituição é cidadã e disciplinou o tema educação de forma mais relevante, reconhecida como direito fundamental, matéria no qual está incluída no rol de direitos sociais na Lei maior artigo 205, definindo três propósitos básicos para a educação: o pleno desenvolvimento da pessoa, seu preparo para o exercício da cidadania e sua qualificação para o trabalho.

Santos (2014), ao citar o Estatuto da Criança e do Adolescente (ECA) - Lei 8.069/1990, fala que os menores, principalmente em idade fundamental, são tidos perante a Lei, como indefesos e aqueles que causam prejuízo a esses pequeninos devem pagar o preço da sonegação do Direito Constitucional em sentido amplo: à educação, á condição social digna, à vida e não vegetação futura a margem da vida normal.

Amaral (2015) comenta que sob o código do processo civil de 1973, as demandas da educação são ajuizadas sob o rótulo das conhecidas ações de obrigação de fazer. Com o novo código de processo civil é autorizado ao juiz a cognição sumária como forma de solucionar a lide. A falta 
de vagas em creches e escolas, desconsideração do critério unicamente meritório para o acesso aos níveis mais elevados do ensino, ausência de transporte escolar para alunos carentes, falta de professores etc, poderão e deverão ser solucionados em cognição sumária via tutela de evidência.

Dantas (2018) entende que a Constituição Federal de 1988 dá protege o cidadão, a LDB por sua vez deslumbra a transformação na educação, nos moldes da Constituição Federal, porém havia a necessidade de um meio que não apenas promovesse a educação à criança, mas que esse direito ficasse resguardado a mesma, daí o surgimento do Estatuto da Criança e do adolescente(ECA), que dispõe em seu artigo $53^{\circ}$ que: A criança e o adolescente têm direito à educação, visando ao pleno desenvolvimento de sua pessoa, preparo para o exercício da cidadania e qualificação para o trabalho.

Moreira (2016) menciona o Plano Nacional de Educação (PNE), aprovado pela Lei $n^{\circ} 10.172 / 2001$, o documento é composto de 20 metas, onde a meta 3 estabelece Universalizar, até 2016, o atendimento escolar para toda a população de 15 a 17 anos, porém, tanto essa meta como a meta 1, que trata do ensino infantil, ficaram ameaçadas e apesar de algumas ações como o "busca ativa" por exemplo, ainda assim, a consecução das metas se torna algo pouco provável, já que nos últimos anos não houve quase nenhuma iniciativa plausível neste sentido.

Pereira (2016) afirma que indisciplina escolar e ato infracional de criança ou de adolescente na escola não compete ao conselho tutelar, sua atuação no âmbito escolar se dá por maus tratos envolvendo os educandos alunos, reiteração de faltas injustificadas e de evasão escolar, quando esgotados os recursos escolares e elevados níveis de repetência.

Nunes (2018) observa em sua pesquisa que a Legislação vigente através da Lei $6.201 / 75$, garante a estudante gestante e mães recentes (adotivas e biológicas), o direito de ser assistida pelo regime de exercícios domiciliares. O propósito da Lei a época, consistia em reduzir a evasão escolar das gestantes, estimulando-as a prosseguir com os estudos básicos.

De acordo com a legislação brasileira, no que se refere ao direito a educação, existe o amparo legal para que todos tenham uma educação de qualidade, no entanto é preciso a adequação das instituições, para que essas garantias sejam respeitadas.

\section{Transporte escolar, demanda básica para 0 acesso à escola.}

Chegar a escola e ter condições de fazer as atividades educacionais com satis- 
fação, é essencial para um bom desempenho do educando, no entanto é preciso uma atenção para que demandas básicas como a do transporte escolar, sejam garantidas.

Amaral (2016) fala da importância do o Art. 206, I, da CF/88, estabelecendo dentre outros, que o ensino será ministrado com base no princípio da igualdade de condições para o acesso e permanência na escola, daí a importância do artigo 208, VII, da $\mathrm{CF} / 88$, determinando ao Estado que a educação de crianças e adolescentes deverá ser efetivada mediante programas públicos de transporte escolar, garantindo a ida a escola dos que moram longe desta, e não tem como pagar a locomoção.

Morais (2015) relata que em Florianópolis a Lei municipal 34/1999, limitava os educandos a 25 de ida e volta para um mês, muito ruim, pois nem todos tinham como completa as 25 restantes. Esta Lei foi modificada pela Lei Complementar Municipal n 490 de 2013, com vigência em $27 / 03 / 2014$, onde foi obtido o direito a recarga livre. A recarga e feita conforme a necessidade do estudante, possibilitando dessa forma o acesso ao educando em outras áreas da sociedade que contribui para formação do cidadão, como a cultura e o lazer.

Segundo Fernandes (2018), além da valorização do trabalho docente, do ambiente adequando ao ensino, da disponibili- zação de materiais didáticos e merenda escolar, outro instrumento importante para efetivação direito social à educação referese ao transporte escolar. Em muitos casos, a falta de transporte escolar adequado é determinante para o aumento do índice de evasão escolar e para o rendimento dos estudantes. Sendo importante, dessa forma, órgão como TCE, a exemplo de Pernambuco, na orientação e fiscalização desse setor.

Entende-se dessa forma que o transporte escolar é fator importante no acesso a escola pelo educando, que tem essa garantia pela legislação vigente.

\section{A evasão escolar diante da realidade so- cial do educando.}

Esta temática compreende artigos que trata da necessidade do Estado de estruturar melhor, tanto a nível profissional quanto de material e estrutura física, a escola, para atender melhor a comunidade escolar, principalmente o educando.

Segundo Duarte (2018), as demandas escolares de cunho social, evidencia a necessidade de atuação do assistente social no ambiente escolar, devido a escola ser receptora das mazelas sociais trazidas pelo educando, a mesma necessita desse profissional para realizar o atendimento às demandas sociais junto a equipe multidisciplinar. A política educacional, na busca do recurso além do profissional da educação 
para incluir no ambiente escolar, necessita dar abertura para intervenção do assistente social, onde trabalhará na prevenção e no enfrentamento da evasão escolar, levando em consideração contexto social em que esses estudantes vivem.

Griffo (2015) afirma que numa sociedade em que o importante é ter e não o ser, é preciso cuidados para que os jovens educandos não embarquem nessa visão, para tanto o estado necessita viabilizar melhor estrutura nos bairros de vulnerabilidade social, para que os jovens tenham atrativo, tenham lazer, esporte, acesso a saúde e educação de qualidade, valorizando assim sua autoestima, evitando a evasão escolar e ficar vulnerável inclusive a prática da criminalidade. É preciso que haja um respeito do Estado como todo com o jovem, enquanto cidadão e enquanto ser humano.

Segundo Cinti (2016), para enfrentar situações com educando com tendência a evasão escolar por variados motivos, inclusive drogas, o ideal dentro das escolas é que tenha a presença de uma vigorosa equipe multidisciplinar composta por psicólogos, assistentes sociais e líderes que poderão ser professores ou estudantes, melhorando os conflitos entre alunos, alunos e professores, professores e familiares de alunos que são existenciais e não devem extrapolar o território escolar e familiar. Essa interação é necessária e contribui para formação ética e cívica dos jovens, fazendo toda diferença no futuro deles.

Uma boa estrutura do ambiente educacional e uma relação mais eficaz dos profissionais da escola com os educandos e seus conflitos, possibilita a frequência mais assídua destes na escola, evitando o abandono e oportunizando a eles um futuro mais promissor.

\section{A importância do comprimento da legis- lação, quanto ao casamento e o trabalho infantil, para o futuro do educando.}

Esta categoria compreende estudos que trata da legislação sobre casamento e trabalho infantil e as consequências da falta de aplicação da Lei, para vida desses jovens.

Licia (2019) comenta que o casamento precoce além de trazer consequências como o desfasamento das fases da infância e adolescência e o crescimento da taxa de natalidade não planejada, traz o aumento da evasão escolar, daí a importância da alteração do código civil Lei 10.406/2002, através da Lei 13.811/2019, que alterou o artigo 1.520, não permitindo, em qualquer caso, o casamento de quem não atingiu a idade núbil.

Lucena (2019) observa que a alteração do artigo 1.520 , não permite o casamento de menores de 16 anos em nenhuma hipótese. Segundo levantamento do banco mundial, divulgado em 2015, o brasil é o 
$4^{\circ}$ país com mais casamentos infantis no mundo, e isso tem correlação direta com a evasão escolar. Fato é que, uma jovem de 14 , ou até mesmo 16 anos não tem a maturidade suficiente para um casamento, com todas responsabilidades que lhes é exigida.

Pirola (2018) afirma que os percentuais de evasão escolar feminina, cerca de $30 \%$, tem uma forte relação com os dados do casamento precoce, no Brasil apesar de quedas nos últimos anos, o número de casamento entre meninas com menos de 16 anos ainda é muito alto. Uma das agendas de enfrentamento sugeridas por estudos do Banco Mundial e outros está relacionada à eliminação de brechas legais para o casamento infantil.

Segundo Freitas (2015), o trabalho infantil, conforme dados da PNUD 2012, ainda vitima mais de três milhões de crianças e adolescentes entre 5 e 17 anos de idade, no Brasil. O trabalho precoce, além de expor a criança a riscos desnecessários (ergonômicos, morais, psíquicos), pode impedir a sua qualificação básica, essencial para o rompimento do ciclo da pobreza, pois não há dúvidas de que a educação ainda é o principal fator de mobilidade social de caráter mais duradouro.

Segundo Alves (2018), no Brasil, é ilegal o trabalho de crianças e adolescentes menores de 16 anos, salvo na condição de aprendiz a partir do 14 (quatorze) anos, porém, o número de crianças inseridas no "mercado de trabalho" ainda que de forma ilegal, é muito grande. Uma das maiores consequências do Trabalho Infantil, é a evasão escolar, e os que frequentam a escola e trabalham, possuem baixos rendimentos escolares.

Turiani (2016) afirma que no Brasil o trabalho infantil é crime, conforme $\mathrm{CF} /$ 1988 e Estatuto da Criança e do Adolescente. Sabe-se que o trabalho infantil prejudica o que esses jovens são afastados do convívio familiar e perdem o tempo valioso que teriam para brincar, descansar e estudar, além de ficarem vulneráveis a diversas formas de violência, que consequentemente pode os levar à queda do desempenho ou ao abandono escolar.

Segundo Medeiros (2018), a família e sociedade devem observar que o trabalho infantil é um problema que muitos entraves causam nas crianças, gerando baixo rendimento escolar, diminuição da autoestima, tão bem como pouco raciocínio e criatividade. É preciso tirar essa criança dessa condição e garantir a ela um processo educacional que seja inclusivo, formador de cidadãos conscientes do seu papel na comunidade.

Apesar do aparato legal para a evitar o trabalho infantil, como também o casamento infantil, essa prática ainda é uma realidade levando os jovens a saírem da escola, interrompendo seus sonhos. 
O processo de inclusão nas escolas, levando em consideração as garantias da Legislação.

Esta temática compreende estudos relacionados ao processo de inclusão dos educandos, tendo como base a garantia da legislação dentro da realidade do sistema de ensino.

Amaral (2018) relata que a legislação brasileira: Constituição Federal, Lei de diretrizes e bases, Estatuto da Criança e do Adolescentes entre outras, torna inaceitável e inadmissível a recusa de oferta regular de educador especial e à criança portadora de deficiência. Mesmo ciente de todo esse amparo legal, a realidade das crianças brasileiras é outra, bem distante da promessa legislativa de reconhecer sem discriminação o direito das pessoas com deficiência à educação.

Segundo Mendes e Patussi (2016), a norma vigente deixa claro a existência de uma parcela grande de pessoas com vários tipos de deficiências, precisando ser integrada no convívio social sem qualquer tipo de descriminação, sendo necessário a educação abrir espaço para essas pessoas e incluir no contexto escolar a aceitação do semelhante sem observar no mesmo sua condição física, no entanto, ainda se faz necessário em muitos casos a imposição da legislação para essa garantia.
Vasconcelos (2016) afirma que que mesmo diante de todo aparato constitucional, muitos são os obstáculos enfrentados pelas pessoas com deficiência para o seu acesso e permanência na escola com igualdade de oportunidades e de tratamento. É preciso consolidar uma educação inclusiva comprometida e pautada nos valores sublimes: bem estar, justiça social e equidade, no propósito de evitar tanto o desestímulo, como a evasão escolar, contribuindo dessa forma com autonomia da vontade das pessoas com deficiência, numa sociedade multicultural e heterogênea.

Amaral (2016) fala em seu estudo que a legislação brasileira é impecável no que diz respeito a garantia de uma educação inclusiva para crianças e adolescentes com deficiência. Mas, é preciso ter uma atenção para o § único, do Art. 27, do Estatuto da Pessoa com Deficiência: "É dever do Estado, da família, da comunidade escolar e da sociedade assegurar educação de qualidade à pessoa com deficiência, colocando-a a salvo de toda forma de violência, negligência e discriminação”. Para uma educação verdadeiramente inclusiva, é preciso da participação de todos.

Diante do exposto observa-se que mesmo com as garantias da legislação, muito precisa ser feito para o acesso e permanência da pessoa com necessidades especiais no sistema educacional. 


\section{A falta de Inclusão dos educandos LGBT no ambiente escolar}

Integra-se nessa exposição temática, trabalhos que tratam do sofrimento e preconceito dos educandos que faz parte do público LGBT, na sociedade e no ambiente escolar.

Ferreira (2017) em sua pesquisa relata que o número de educandos transgêneros que abandonam a escola chega a $82 \%$ devido à falta de políticas de inclusão. O Princípio de Yogyakarta em 2006 estabelece o direito à educação sem discriminação por Orientação Sexual ou Identidade de Gênero, entretanto, a legislação brasileira já garantia, que a educação deve ser inspirada "nos princípios de liberdade e nos ideais de solidariedade humana, tem por finalidade o pleno desenvolvimento do educando, seu preparo para o exercício da cidadania e sua qualificação para o trabalho", prezando pelo "respeito à liberdade e apreço à tolerância". Educar para a diversidade é um dever das escolas.

Segundo Silva (2018), o uso do nome social para pessoas trans foi legitimado pelo MEC, podendo ser colocado na matrícula do educando, o que melhorou, mas o preconceito ainda leva transexuais a abandonar a escola. O nome não pode ser alterado nos documentos oficiais, o que leva a pessoa trans a passar por constrangimentos, no entanto, neste ano em julgamentos históricos, o Tribunal Superior Eleitoral (TSE) e o Supremo Tribunal Federal (STF) afirmaram a humanidade, dignidade, cidadania e autonomia das pessoas transexuais e travestis, ao reconhecerem seu direito de soberana autodefinição de sua identidade de gênero e a necessidade de respeito a pessoas enquanto tais.

Sigabinazze (2016) afirma que apesar de haver a tutela jurisdicional do direito à identidade e à dignidade sexual do transexual, a efetivação de tal direito está longe de ocorrer, com a falta de campanhas sociais para educar a população de forma mais efetiva faz ocorrer a perpetuação dos preconceitos, causando graves consequências que vão desde a evasão escolar, com a consequente exclusão do mercado de trabalho formal, até a morte.

Magalhães (2016) relata que as situações vexatórias, violentas e opressoras contra gays, lésbicas, bissexuais, travestis e transexuais, são os principais fatores que colaboram com a evasão escolar desses educandos. O reconhecimento oficial do nome social torna-se um passo importante no sentido de romper as barreiras do preconceito em um mundo em que a sociedade estabelece o que não lhe corresponde ao "normal".

Apesar de avanços nas garantias legais, a violência e o preconceito fazem com 
que muitos do grupo LGBT, principalmente o transgênero, evadam da escola

\section{CONCLUSÃO}

Diante do exposto, observa-se que a Legislação Brasileira é bastante abrangente no que diz respeito ao direito a educação de qualidade, assegurando para todos o acesso à escola, no entanto sabe-se que não é essa a realidade. Mesmo diante de um emaranhado de leis e suas garantias, é notório a falta de estrutura da educação, e a falha na garantia dos direitos fundamentais da criança e do adolescente, como consequência o que se tem é um número considerável de jovens fora da escola.

Vários motivos levam a evasão escolar, dentre eles: vulnerabilidade do ambiente em que moram, devido à falta de estrutura; precariedade do transporte escolar, principalmente para o educando que moram

\section{REFERÊNCIAS}

Alves, Jhessica Sâmia Lins. Erradicação do trabalho infantil: Possibilidades. Jusbrasil, 2018. https://jhessicasamia.jusbrasil.com.br/artigos/561376252/erradicacaodo-trabalho-infantil-possibilidades? ref=serp.

Amaral, Carlos Eduardo Rios do. Educação inclusiva é responsabilidade de todos nós. Jusbrasil, 2016. https://eduardoamaral74.jusbrasil.com.br/artigos/340844653/educacao-inclusiva-e-responsabilidade-de-todos-nos?ref=serp deixando para trás a oportunidade de uma formação para o mercado de trabalho. em área de difícil acesso; casamento infantil, infelizmente ainda com índice alto; gravidez precoce; trabalho infantil e precariedade do sistema educacional de um modo geral como falha no processo de inclusão, que vai desde as condições de ensino para o especial, como o preconceito e a falta de estrutura física das escolas, principalmente quanto a acessibilidade. Infelizmente a proteção das leis, ainda não evita situações como essas, que é uma parte dos problemas que causam de forma significativa, o fracasso escolar.

Por fim, observa-se que a falta de políticas públicas eficazes, para questões relacionadas a condição social do educando, a acessibilidade, a inclusão e a estrutura da escola, provocam o desrespeito às leis, tendo como consequência o alto índice de evasão escolar.

Amaral, Carlos Eduardo Rios do. Tutela de evidência solucionará demandas de educação no Novo CPC. Jusbrasil, 2015. https://eduardoamaral74.jusbrasil.com.br/artigos/298438175/tutela-deevidencia-solucionara-demandas-de-educacao-no-novo-cpc?ref=serp

Amaral, Carlos Eduardo Rios do. Transporte escolar, garantia de acesso à educação. JusbrasiL, 2016. https://eduardoamaral74.jusbrasil.com.br/artigos/308629001/transporte-escolar-garantia-de-acesso-a-educacao?ref=serp 
Amaral, Carlos Eduardo Rios do. Criança com deficiencia tem direito a educador especial em sala de aula. Jusbrasil, 2018. https://eduardoamaral74.jusbra-

sil.com.br/artigos/623255821/crianca-comdeficiencia-tem-direito-a-educador-especial-em-sala-de-aula?ref=serp

Cinti, Maria da Conceição Damasceno. Evasão Escolar: Causas e soluções. Jusbrasil, 2015. https://conceicaocinti.jusbrasil.com.br/artigos/405075029/evasao-escolar-causas-e-solucoes? $\mathrm{ref}=$ serp

Constituição Federal do Brasil, 1988. http://portal.mec.gov.br/setec/arquivos/pdf_legislacao/superior/legisla_superior_const.pdf

Dantas, Nelma Gomes de Araújo. ECA e a Escola - Um Estado de Vivência e Cidadania. Jusbrasil, 2018. https://nelmadantas.jusbrasil.com.br/artigos/569404218/eca-e-a-escola-um-estadode-vivencia-e-cidadania?ref=serp

Duarte, Ana Paula Pires. A atuação profissional do Assistente Social na garantia de direitos no ambiente escolar. Jusbrasil, 2018. https://anapauladuartefroid.jusbrasil.com.br/artigos/610016724/a-atuacaoprofissional-do-assistente-social-na-garantia-de-direitos-no-ambiente-escolar? $\mathrm{ref}=$ serp.

Ferreira, Bruno. Educação pela diversidade: 05 maneiras de transformar espaços de ensino em lugares seguros para jovens LGBTQ. Jusbrasil, 2017. https://bfferreirabruno.jusbrasil.com.br/artigos/530039979/educacao-pela-diversidade-05-maneiras-de-transformar-espacosde-ensino-em-lugares-seguros-para-jovenslgbtq? ref=serp.

Freitas, Graça Maria Borges. Trabalho infantil e educação: Avanços necessários. Jusbrasil, 2015. https://daniellixavierfreitas.jusbrasil.com.br/artigos/168147845/tra- balho-infantil-e-educacao-avancos-necessarios-artigo-de-graca-maria-borges-defreitas?ref $=$ serp

Fernandes, José Ulisses Jacoby. Controle de contratos de transporte escolar e iniciativa do TCE/PE. Jusbrasil, 2018. https://jacobyfernandes.jusbrasil.com.br/artigos/565350113/controles-de-contratos-detransporte-escolar-e-iniciativa-do-tcepe?ref=serp

Griffo, Luciana Maria Silva. A inserção social da juventude na sociedade do consumo: Mediação da Educação e do Trabalho. Jusbrasil, 2015. https://lucianagriffo.jusbrasil.com.br/artigos/178675950/ainsercao-social-da-juventude-na-sociedade-do-consumo-mediacao-da-educacaoe-do-.trabalho?ref=serp

Licia, Brenda. Casamento infantil: a Lei 13.811/2019 e seus reflexos jurídicos. Jusbrasil, 2019. https://brendaliciaalmeida.jusbrasil.com.br/artigos/729685815/casamento-infantil-a-lei-13811-2019-e-seus-reflexos-juridicos?ref=serp

Leite, Gisele. $O$ direito a educação no cenário brasileiro. Jusbrasil, 2016. https://professoragiseleleite.jusbrasil.com.br/artigos/327548027/o-direito-aeducacao-no-cenario-brasileiro?ref=serp

Lucena, Lorena. Quem pode casar? Análise da Lei $n^{\circ} 13.718 / 18$, que tipifica os crimes de importunação sexual e de divulgação de cenas de estupro. Direito das Famílias e Direito Civil. JUSBRASIL, 2019. https://lucenatorres.jusbrasil.com.br/artigos/696439759/quem-pode-casar-analiseda-lei-n-13718-18-que-tipifica-os-crimesde-importunacao-sexual-e-de-divulgacaode-cenas-de-estupro?ref=serp

Medeiros, Karolina Teixeira Alan. Trabalho Infantil: aspectos históricos, implicações na sociedade e familia. Jusbrasil, 2018. https://karolinaealan.jusbra- 
sil.com.br/artigos/636224616/trabalho-infantil-aspectos-historicos-implicacoes-nasociedade-e-familia?ref=serp

Mendes, Jaedson Farias e Patussi, Raquel Ianguas Greco. INCLUSÃO ESCOLAR: Uma verdadeira justiça poética. Jusbrasil, 2016. https://davimendes.jusbrasil.com.br/artigos/408820447/inclusao-escolar-uma-verdadeira-justica?ref=serp

Morais, Anderson. Lei Recarga Livre: vitória dos estudantes e da sociedade. Jusbrasil, 2015. https://andersonmorais.jusbrasil.com.br/artigos/186792487/lei-recargalivre-vitoria-dos-estudantes-e-da-sociedade? ref $=$ serp

Moreira, Camila. A meta 3 do PNE e a evasão escolar. Jusbrasil, 2016. https://cmoreira2.jusbrasil.com.br/artigos/328111780/a-meta-3-do-pne-e-a-evasao-escolar?ref $=$ serp

Moreira, Camila. Nota técnica - Evasão escolar-Motivos. Jusbrasil, 2019. https://cmoreira2.jusbrasil.com.br/artigos/717147997/nota-tecnica-evasao-escolar-motivos?ref=serp

Nunes, Alynne Nayara Ferreira. Gestante, mãe e estudante: quais são os meus direitos? Jusbrasil 2018. https://naya773.jusbrasil.com.br/artigos/581326261/gestantemae-e-estudante-quais-sao-os-meus-direitos?ref $=$ serp

Pinto, Fabiana Vilela de Araújo Magalhães. $O$ direito ao uso do nome social. Jusbrasil, 2016. https://villelamagalhaes.jusbrasil.com.br/artigos/391645575/o-direito-ao-uso-do-nomesocial?ref $=$ serp

Pereira, Rafael do Nascimento. O ConseIho Tutelar e a Escola: Relação Harmônica. Jusbrasil, 2016. https://rafaelconselhotutelar.jusbrasil.com.br/artigos/406162997/o-conselho-tutelar-e-a-escola?ref=serp
Pirola, Antonio Luiz Rocha. A tragédia do casamento infantil. Jusbrasil, 2018. https://tompirola.jusbrasil.com.br/artigos/587398862/a-tragedia-do-casamentoinfantil?ref=serp

Presidência da República, Casa Civil. Lei de Diretrizes e Bases da Educação Brasileira. Lei $n^{\circ} 9.394$, de 20 de dezembro de 1996. http://www.planalto.gov.br/ccivil_03/LEIS/L9394.htm

Presidência da República, Secretaria Geral. Estatuto da Pessoa com Deficiência. Lei $n^{o}$ 13.146, de 06 de julho de 2015. http://www.planalto.gov.br/ccivil_03/_ato2015-2018/2015/lei/113146.htm

Presidência da República, Casa Civil. Estatuto da Criança e do Adolescente. Lei $n^{o}$ 8.069, de 13 de julho de 1990. http://www.planalto.gov.br/ccivil_03/leis/18069.htm

Santos, Mauro Martins de Paula Orlando. O direito constitucional à educação, criminalização. Jusbrasil, 2014. https://mauromartinsdepaulaorlandosantos.jusbrasil.com.br/artigos/140852322/o-direitoconstitucional-a-educacao-criminalizacao?ref=serp

Silva, Geisson. O uso do nome social para trans e travesti. Jusbrasil, 2018, https://geissonro.jusbrasil.com.br/artigos/654121951/o-uso-do-nome-socialpara-trans-e-travestis?ref-serp

Sigabinazze, Alexandre. Do direito do transexual no direito brasileiro. Jusbrasil, 2016. https://alexandremarcello.jusbrasil.com.br/artigos/396019201/do-direitodo-transexual-no-direito-brasileiro?ref $=$ serp 
Turiani, Carolline. Trabalho Infantil. Jusbrasil, 2018. https://carollineturiani.jusbrasil.com.br/artigos/398459746/trabalho-infantil?ref=serp

Vasconcelos, Henrique. Educação inclusiva como instrumento de inclusão na sociedade plural contemporânea. Jusbrasil,
2016. https://hdsvs25.jusbrasil.com.br/artigos/380198964/educacao-inclusiva-comoinstrumento-de-inclusao-na-sociedade-plural-contemporanea?ref=serp] 